\title{
Spring bloom dynamics and zooplankton biomass response on the US Northeast Continental Shelf
}

\author{
Kevin D. Friedland ${ }^{\text {a,* }}$, Robert T. Leaf ${ }^{b}$, Joe Kane ${ }^{a}$, Desiree Tommasi ${ }^{c}$, Rebecca G. Asch ${ }^{d}$, \\ Nathan Rebuck ${ }^{a}$, Rubao Ji ${ }^{\mathrm{e}}$, Scott I. Large ${ }^{\mathrm{f}}$, Charles Stock ${ }^{\mathrm{c}}$, Vincent S. Saba ${ }^{\mathrm{g}}$ \\ a National Marine Fisheries Service, Northeast Fisheries Science Center, 28 Tarzwell Dr., Narragansett, RI 02882, USA \\ ${ }^{\mathrm{b}}$ Gulf Coast Research Laboratory, University of Southern Mississippi, 703 East Beach Drive, Ocean Springs, MS 39564, USA \\ c NOAA Geophysical Fluid Dynamics Laboratory, Princeton University Forrestal Campus, 201 Forrestal Road, Princeton, NJ 08540, USA \\ ${ }^{\mathrm{d}}$ Princeton University, Program in Atmospheric and Oceanic Sciences, 300 Forrestal Road, Princeton, NJ 08540, USA \\ e Department of Biology, Woods Hole Oceanographic Institution, Woods Hole, MA 02543, USA \\ ${ }^{\mathrm{f}}$ National Marine Fisheries Service, Northeast Fisheries Science Center, 166 Water Street, Woods Hole, MA 02543, USA \\ ${ }^{\mathrm{g}}$ National Marine Fisheries Service, Northeast Fisheries Science Center, c/o NOAA Geophysical Fluid Dynamics Laboratory, 201 Forrestal Road, Princeton \\ University Forrestal Campus, Princeton, NJ 08540, USA
}

\section{A R T I C L E I N F O}

Article history:

Received 31 October 2014

Received in revised form

20 February 2015

Accepted 3 April 2015

Available online 7 April 2015

Keywords:

Spring bloom

US Northeast Shelf

Zooplankton biomass

Bloom timing

Climate

\begin{abstract}
A B S T R A C T
The spring phytoplankton bloom on the US Northeast Continental Shelf is a feature of the ecosystem production cycle that varies annually in timing, spatial extent, and magnitude. To quantify this variability, we analyzed remotely-sensed ocean color data at two spatial scales, one based on ecologically defined sub-units of the ecosystem (production units) and the other on a regular grid $\left(0.5^{\circ}\right)$. Five units were defined: Gulf of Maine East and West, Georges Bank, and Middle Atlantic Bight North and South. The units averaged $47 \times 10^{3} \mathrm{~km}^{2}$ in size. The initiation and termination of the spring bloom were determined using change-point analysis with constraints on what was identified as a bloom based on climatological bloom patterns. A discrete spring bloom was detected in most years over much of the western Gulf of Maine production unit. However, bloom frequency declined in the eastern Gulf of Maine and transitioned to frequencies as low as 50\% along the southern flank of the Georges Bank production unit. Detectable spring blooms were episodic in the Middle Atlantic Bight production units. In the western Gulf of Maine, bloom duration was inversely related to bloom start day; thus, early blooms tended to be longer lasting and larger magnitude blooms. We view this as a phenological mismatch between bloom timing and the "top-down" grazing pressure that terminates a bloom. Estimates of secondary production were available from plankton surveys that provided spring indices of zooplankton biovolume. Winter chlorophyll biomass had little effect on spring zooplankton biovolume, whereas spring chlorophyll biomass had mixed effects on biovolume. There was evidence of a "bottom up" response seen on Georges Bank where spring zooplankton biovolume was positively correlated with the concentration of chlorophyll. However, in the western Gulf of Maine, biovolume was uncorrelated with chlorophyll concentration, but was positively correlated with bloom start and negatively correlated with magnitude. This observation is consistent with both a "top-down" mechanism of control of the bloom and a "bottom-up" effect of bloom timing on zooplankton grazing. Our inability to form a consistent model of these relationships across adjacent systems underscores the need for further research.
\end{abstract}

Published by Elsevier Ltd.

\section{Introduction}

The US Northeast Continental Shelf is a segment of the Northwest Atlantic Shelves Biogeographical Province comprising shelf ecosystems of the western boundary of the Atlantic basin. The ecosystem is structurally complex compared to other shelf

\footnotetext{
* Corresponding author.

E-mail address: kevin.friedland@noaa.gov (K.D. Friedland).
}

systems in that it contains a variably dimensioned shelf, multiple deep basins, and an elevated bank (Sherman et al., 1996). This complexity extends to seasonal phytoplankton bloom patterns where the northern and southern parts of the ecosystem are continuous with trans-Atlantic bands of ecosystems that either have a bimodal or a single autumn/winter annual bloom cycle, respectively (Taboada and Anadon, 2014). The relative stability of bloom dynamics suggested by climatological patterns is in contrast to the variability observed spatially and temporally within ecosystems. Regional analyses often reveal complex patterns of meso- 
scale heterogeneity in bloom dynamics often related to features of the underlying physical environment (Zhao et al., 2013), the physiochemical regime of the ecosystem (Shiozaki et al., 2014), or inter-annual variability of the wind regime (Chiswell et al., 2013; Navarro et al., 2012). However, broad-scale climate dynamics such as the North Atlantic Oscillation (Zhai et al., 2013) and El Nino/ Southern Oscillation (D'Ortenzio et al., 2012) can influence coherent patterns of bloom dynamics. There is also evidence that duration and size composition of phytoplankton blooms can be influenced by the grazing activity of micro-zooplankton (Chen et al., 2013) and meso-zooplankton (Hlaili et al., 2014).

The dynamics of the spring bloom on the Northeast Shelf have been considered from both observational and modeling perspectives. The primary source of nutrients into the Northeast Shelf derive from deep, off-shelf waters that enter the shelf via the Northeast Channel in the Gulf of Maine and between Browns Bank and the Eastern Scotian Shelf (Townsend et al., 2010). Moreover, cold and fresh water shelf intrusions from the north via the Labrador Current can also affect the water properties in the Gulf of Maine (Townsend et al., 2006). Prior to each spring, winter mixing replenishes nutrients in surface waters that set the nutrient reservoir for the ensuing spring bloom. Inter-annual variability in the relative proportions of these shelf and slope source waters can affect the nutrient content and salinity of the Gulf of Maine and Georges Bank waters (Townsend et al., 2010).

The timing of the Northeast Shelf spring bloom was first examined in remote sensing data in an effort to develop a baseline understanding of the production cycle of the Gulf of Maine (Thomas et al., 2003). As the remote sensing datasets matured, more complete analyses were accomplished. Focusing on the Gulf of Maine and Scotian Shelf region, Song et al. (2010) found that spring bloom timing was correlated with sea surface salinity, which was associated with the changing pattern of Arctic freshening in the Gulf of Maine in recent years (Townsend et al., 2010). Modeling studies of the Gulf of Maine region have also focused on the role of physical processes controlling water column control stability as the primary mode of bloom initiation (Ji et al., 2008).

The timing of the spring bloom has been associated with recruitment success of fish species, thus heightening our interest in the bloom dynamics. The hypothesis that fish year-class strength is determined by food availability during a critical larval stage, which is maximized when the timing of the spring bloom occurs at a suitable lag from the time of spawning was first put forward by Hjort (1914) and then expanded upon by Cushing (1990). The Hjort-Cushing match/mismatch hypothesis has now been demonstrated for a variety of fish species. In cod, the match-mismatch dynamics between larval fish and their zooplankton prey has been associated with the timing of the spring bloom (Kristiansen et al., 2011). For the allied species haddock, early spring blooms have been associated with survivor ratio (Platt et al., 2003; Trzcinski et al., 2013). The relationship between bloom timing and recruitment can involve a more nuanced relationship between zooplankton and larval fish. Year-class strength of walleye pollock has also been associated with variation in zooplankton composition related to phytoplankton phenology (Hunt et al., 2011). Spring bloom dynamics have also been observed to influence recruitment success of Argentine anchovy, Pacific herring, and coho and sockeye salmon (Borstad et al., 2011; Chittenden et al., 2010; Marrari et al., 2013; Schweigert et al., 2013).

Many fish species have early life stages that are dependent on associations with specific spring zooplankton communities, heightening our interest in the role of the spring bloom in shaping spring zooplankton community structure. It is well established that the spring bloom marks the beginning of zooplankton production in temperate marine systems (Longhurst, 1995). Spring phytoplankton dynamics can affect both the build-up of copepod spring biomass (Chiba and Saino, 2003; Kiorboe and Nielsen, 1994; Tommasi et al., 2013b), as well as zooplankton species composition (Chiba et al., 2008; Tommasi et al., 2013a). Differences in zooplankton community structure may be linked to differential dependencies of specific zooplankton taxa on spring bloom phenology. Survival of early copepodites of large, lipid rich copepods such as Calanus finmarchicus or Calanus marshallae, is highest when their appearance matches the onset of the spring bloom (Baier and Napp, 2003). Thus, the timing of reproduction has to occur at a critical lag with phytoplankton spring phenology for their next generation to be recruited successfully (Baier and Napp, 2003; Broms and Melle, 2007; Soreide et al., 2010). In contrast to other regions, over the Northeast shelf the mechanisms driving variability in spring dominant copepods, such as C. finmarchicus, remain elusive (Hare and Kane, 2012; Pershing et al., 2010). Assessing how spring bloom dynamics relate to shifts in spring zooplankton biomass is a first essential step to uncovering the potential mechanism driving spring zooplankton variability in the region. However, from the outset we have to be circumspect about the role of the spring bloom since there is evidence to suggest that winter blooms in the Gulf of Maine may play an important role in shaping spring zooplankton populations by fostering extra generations of key species like of $C$. finmarchicus during winter (Durbin et al., 2003).

Because of the low amount of recycling and an uncoupling between primary production and consumers, the exported carbon biomass of spring blooms is relatively large (Legendre, 1990). Such uncoupling of primary production and primary consumers is a characteristic of spring blooms on Georges Bank, where a large fraction of the phytoplankton is not grazed (Dagg and Turner, 1982). The ungrazed component of the bloom is exported to the benthos, as particulate organic carbon, and the magnitude of the flux is mediated by physical and biological processes, notably the magnitude of aggregation of particles (Wassmann, 1998). The magnitude of benthic flux in the summer is likely considerably lower than the spring because the phytoplankton biomass on the northeast continental shelf in the summer is lower than that of the spring (O'Reilly and Zetlin, 1998) and because of the timing of the bloom initiation and duration. On a global scale, this likely contributes to the pattern of fisheries production in large marine ecosystem, which correlates with system chlorophyll concentration taken as an indicator of the potential for benthic flux (Friedland et al., 2012).

The goal of this study was to characterize the location, timing, and size of spring season transitional blooms occurring in the US Northeast Shelf large marine ecosystem and elucidate the relationship between bloom dynamics and the mesozooplankton community. A gridded spatial characterization of the ecosystem was employed to best understand the dynamics of blooms associated with specific habitats. Owing to the coarser spatial distribution of zooplankton biomass data, a spatial analysis based on five ecologically defined sub-units of the Northeast Shelf (production units) was also employed. We went on to consider a measure of the timing of spring warming as a factor controlling spring bloom timing. Using a production unit characterization of bloom dynamics, we sought to determine whether the spring bloom influences the biomass of spring zooplankton or whether zooplankton may affect the size of the spring bloom through topdown control. Finally, we examined zooplankton species composition associated with variation in zooplankton biomass in order to determine which species may have influenced the observed relationships between spring bloom dynamics and zooplankton biovolume. 


\section{Methods}

\subsection{Characterization of the spring bloom}

The spring bloom dynamics of the US Northeast Continental Shelf were characterized using chlorophyll- $a$ concentrations based on remote sensing data. The distribution of blooms was evaluated over ecosystem spatial divisions and a sub-ecosystem spatial grid. Ecosystem spatial divisions were established using five production units: Gulf of Maine East and West, Georges Bank, and Middle Atlantic Bight North and South (Fig. 1). The units ranged in size from $37 \times 10^{3}$ to $55 \times 10^{3} \mathrm{~km}^{2}$. The production units in part reflect division of the Shelf ecosystem based on multiple physical and biological factors and patterns of biological resource exploitation (Lucey and Fogarty, 2013), but also take into account the spatial distribution of spring bloom characteristics. The gridded spatial analysis was based on a $0.5^{\circ}$ square spatial grid that circumscribed the extent of all production units (Fig. 1).

Chlorophyll-a concentrations were based on remote-sensing measurements made with the Sea-viewing Wide Field of View (SeaWiFS) and Moderate Resolution Imaging Spectroradiometer (MODIS) sensors. We used the level-3 processed data, at $9 \mathrm{~km}$ and 8-day spatial and temporal resolutions, respectively, obtained from the Ocean Color website (oceancolor.gsfc.nasa.gov). These two sensors provide an overlapping time series of chlorophyll-a concentrations during the period 1998-2013. An analysis restricted to the overlapping period of data from both sensors revealed a bias between the two sensors. We corrected for this bias by calculating factors applied to MODIS data to approximate the mean levels of the SeaWiFS data. Factors $<1$ were indicative of an underestimation of chlorophyll concentration by MODIS compared to SeaWiFS, whereas factors $>1$ were used if SeaWiFS overestimated chlorophyll relative to MODIS. The factors were computed on time (8-day period) and spatial (production units) scales. The bias corrections were greatest in April when the factors were on the order of $\approx 0.8$, were slightly greater in March and May averaging $\approx 0.95$, and were close to unity in the other months of the first half of the year.

In addition to the bias between sensors, remotely sensed chlorophyll concentration estimates are affected by the presence of colored dissolved organic matter (CDOM) and suspended

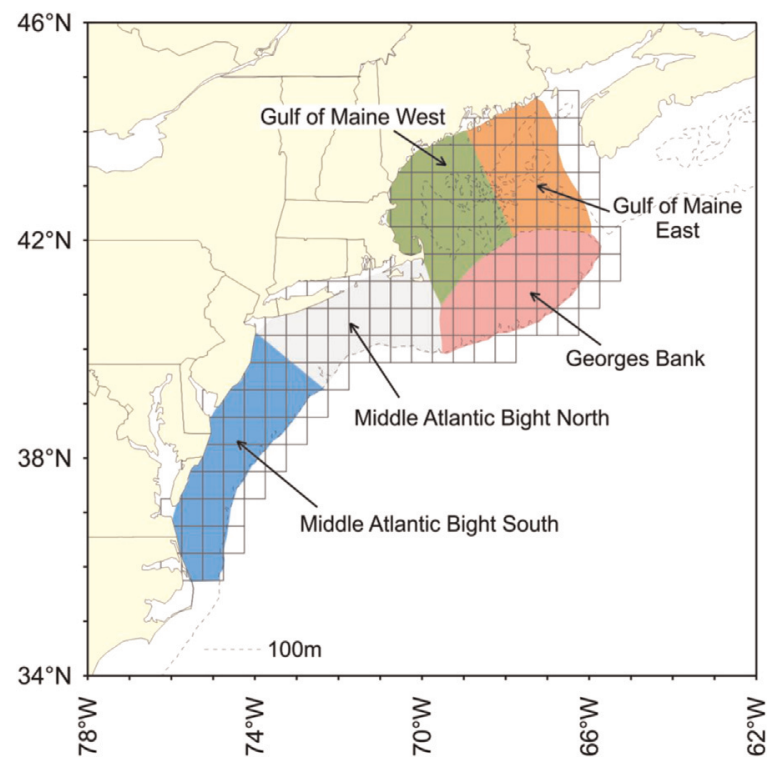

Fig. 1. Map of US Northeast Continental Shelf with half-degree grid (gray lines) and five production units used to spatially characterize chlorophyll and zooplankton data. sediments in coastal waters (Balch et al., 2004). The influences of CDOM and sediments are the strongest in the bays and estuaries on the Northeast Shelf, which were not part of the study area. However, CDOM and sediments can appear episodically over much of the study area due to storms and other weather events (Sosik et al., 2001). We extracted estimates of CDOM from the Ocean Color website to test whether CDOM was systematically trending during the study time series or if CDOM was correlated with chlorophyll concentration. Based on an analysis of CDOM for the five study production units, the only coherent time series trend we detected was limited to 8-day periods during late May and June in the Middle Atlantic Bight (see supplementary material). The only significant correlation between chlorophyll concentration and CDOM were negative in sign, suggesting that the presence of CDOM was not influencing the pattern of chlorophyll concentration on the Northeast Shelf. We view the presence of these materials in the water column as a source of error in our analysis but not a data bias.The chlorophyll-a concentrations $\left(\mathrm{mg} \mathrm{m}^{-3}\right)$ were calculated by taking the average of the constituent pixels for each spatial-temporal cell. For the production unit analysis, 80 (16 years by 5 production units) time series were assembled for first-half-ofthe-year chlorophyll-a concentration. Each first half of the year time series consisted of 23 8-day chlorophyll sample periods starting on day 1 of the year and ending on day 177 (beginning of January to the end of June). For the gridded analysis, 2368 (16 years by 148 grid locations) time series were assembled for firsthalf-of-the-year chlorophyll concentration. Only time series with a minimum of 12 observations per year were considered for analysis. We used linear interpolation to fill missing values within the extent of the data and filled missing values at the beginning and end of the time series with first and last observations, respectively, thus completing the time series for the bloom analysis.

We identified the beginning and end of the spring bloom in each chlorophyll concentration time series using change-point analysis. The sequential averaging algorithm called STARS or "sequential $t$-test analysis of regime shifts" (Rodionov, 2004, 2006) was used to find all change points in a time series. STARS algorithm parameters were specified a priori: the alpha level used to test for a change in the mean was set to $\alpha=0.1$; the length criteria, the number of time steps to use when calculating the mean level of a new regime, was set to 5; and, the Huber weight parameter, which determines the relative weighting of outliers in the calculation of the regime mean, was set to 3 . A bloom was considered to have occurred if there was a period bracketed by a positive and negative change-point. We ignored change-points (positive or negative) that occurred in the first or last two periods (days 1 and 8, and days 169 and 177). A detected bloom could not exceed nine sample periods (approximately 2.4 months), which was based on analyses of climatological bloom patterns in the production units. Periods bracketed by positive and negative change-points exceeding nine 8-day periods were considered to be ecologically different from discrete spring blooms. This method has been used in previous analyses of Northeast Shelf bloom patterns (Friedland et al., 2008, 2009) and elsewhere (Friedland and Todd, 2012).

For each detected bloom, we extracted statistics to characterize bloom timing, intensity, and magnitude. Bloom start was defined as the day of initiation of the spring bloom, which was the first day of the 8-day bloom period that exhibited bloom conditions. Bloom intensity was the average of the chlorophyll concentrations during the bloom period. Bloom magnitude was the integral of the chlorophyll concentrations during the bloom period.

\subsection{Winter and proximate month chlorophyll concentration}

Two fixed temporal reference chlorophyll concentration indices were computed to test the effect of phytoplankton biomass on 
spring zooplankton biomass. Distinct winter blooms are episodic events; however, overwintering chlorophyll levels can be highly variable across the Northeast Shelf ecosystem and zooplankton abundance in the Gulf of Maine can be influenced by these winter blooms (Durbin et al., 2003). Thus, a winter phytoplankton index was developed by computing the average chlorophyll concentration for each production unit over January and February. Second, to test the effect of feeding opportunity on zooplankton biomass during the spring bloom, a fixed spring bloom chlorophyll index was calculated. The index was was simply the average chlorophyll concentration for the month of April for the Gulf of Maine and Georges Bank production units and March for the Middle Atlantic Bight units reflecting the same months used to develop the zooplankton biomass index in each area, respectively. We refer to this index as the proximate month chlorophyll concentration index.

\subsection{Spring thermal transition}

The variation in the phenology of spring thermal conditions was characterized using the date of arrival of a spring transition temperature, which varied by production unit. The transition temperature is the average annual temperature for each production unit. Temperature estimates were made using the NOAA Optimum Interpolation 1/4 Degree Daily Sea Surface Temperature Analysis (OISST). The OISST dataset provides high resolution SST with a spatial grid resolution of $0.25^{\circ}$ and temporal resolution of 1 day (Reynolds et al., 2007). The dataset uses in situ data from ships and buoys as a means of adjusting for biases in satellite data. For each year, the daily data was smoothed with a 5-point moving average filter; the first day of the year that exceeded the transition temperature was scored as the spring transition date for that year.

\subsection{Production unit zooplankton biovolume and species composition}

Zooplankton biovolume, which is a proxy for biomass, was derived from sampling performed by shipboard surveys of the U.S. Northeast Shelf ecosystem. From 1977 to 1987, the MArine Resources Monitoring, Assessment, and Prediction (MARMAP) program conducted intensive surveys from Cape Hatteras, North Carolina to Nova Scotia. These efforts continued at a reduced level through the 1990s and are ongoing today as the Ecosystem Monitoring program (EcoMon). Currently, the EcoMon program tries to collect 120 plankton samples 6 times a year over the Northeast Shelf ecosystem. Sample tows are oblique paired $61 \mathrm{~cm}$ diameter bongo trawls made with a $335 \mu \mathrm{m}$ mesh to a maximum depth of $200 \mathrm{~m}$ distributed in a stratified random sampling design. Biovolume was determined by measuring the settled volume of the sample (Harris et al., 2000). Zooplankton were identified to the lowest taxonomic level possible, resulting in taxa-specific data on abundance and distribution (Kane, 2007). Biovolume and taxa specific abundance from April tows for Gulf of Maine and Georges Bank production units and March tows for the Middle Atlantic Bight units were post-stratified for comparison to proximate month chlorophyll and bloom indices. In addition to the fixed temporal reference for computing a zooplankton biovolume index, we also computed a dynamic zooplankton index by only using tows that were made during the bloom period for each production unit by year. During the MARMAP survey period, a body-length measurement was collected for most zooplankton taxa, which was used to assign a mean length by taxa associated with March and April data collections.

\subsection{Relationships between chlorophyll and bloom indices and zoo- plankton biomass}

The relationships between fixed temporal reference chlorophyll concentration indices and zooplankton biomass, as well as between spring bloom indices and zooplankton biomass, were tested using Pearson product-moment correlation. Correlations between winter and proximate month chlorophyll concentrations and zooplankton biovolume were calculated for all five production units. For this analysis, data were available for all 16 years of the time series. For these and subsequent correlations, all variables were tested for normality and log transformed if indicated. Correlations between bloom statistics and zooplankton biomass were limited to production units with at least eight blooms (i.e., the same criteria used in the correlation analysis of gridded data). This excluded the Middle Atlantic Bight units from this portion of the analysis. Furthermore, two measures of zooplankton biovolume were correlated with the bloom statistics; a fixed index based on zooplankton tows from April only and a dynamic index based on tows that overlapped the spring bloom period for each year by area. In the fixed approach, some observations were excluded if the bloom started in late April or beyond, reasoning that the bloom has to occur before or contemporarily to when the zooplankton data is collected for the comparison to be relevant. The second measure, using zooplankton tows during the bloom period only, preserved more observations since most bloom periods had associated tows. Box plots showing the distribution of quartiles, with whiskers showing the extent of outliers, were provided for selected variables to judge the relative merits of some correlations.

\section{Results}

\subsection{General spring bloom patterns}

The spring bloom is a prominent feature in most areas of the Northeast Shelf ecosystem. Change-point analyses of the mean or climatological chlorophyll concentrations of the Northeast Shelf production units from 1998 to 2013 yielded patterns showing that the Gulf of Maine, Georges Bank, and the northern Middle Atlantic Bight units each have detectable spring blooms (Fig. 2). However, the dimensions and timing of these blooms varies regionally. The earliest blooms occurred in the northern Middle Atlantic Bight with a start day of 73 (March 13); these blooms had an average duration of five 8-day periods. The blooms in the eastern Gulf of Maine and on Georges Bank units tended to start later in the spring on day 81 (March 21). The western Gulf of Maine bloom was of short duration and appeared to have the highest associated chlorophyll concentrations among the productions units. Spring blooms in the Middle Atlantic Bight area were not prominent features and were undetected in the mean chlorophyll data. In part, this can be attributed to high chlorophyll concentrations that persist through the winter months, and thus any spring bloom activity cannot always be distinguished from the winter baseline level.

\subsection{Gridded spring bloom analysis}

The nature of the spring bloom varies widely across the marine habitats of the Northeast Shelf. The spring bloom is not always a detectable feature in all years over much of the shelf. The highest bloom frequencies, those in excess of 0.9 and thus indicating that spring blooms were detected in most years, were limited to the southern, interior portion of the Gulf of Maine and the outer margin (east of the shelfbreak front) of the Middle Atlantic Bight (Fig. 3a). Most of the interior portion of the Middle Atlantic Bight had low spring bloom frequencies generally less than 0.3 . It would appear that the shelfbreak front feature of the Middle Atlantic Bight separates distinct regions with differing spring production patterns. Georges Bank had a range of spring bloom responses; the 


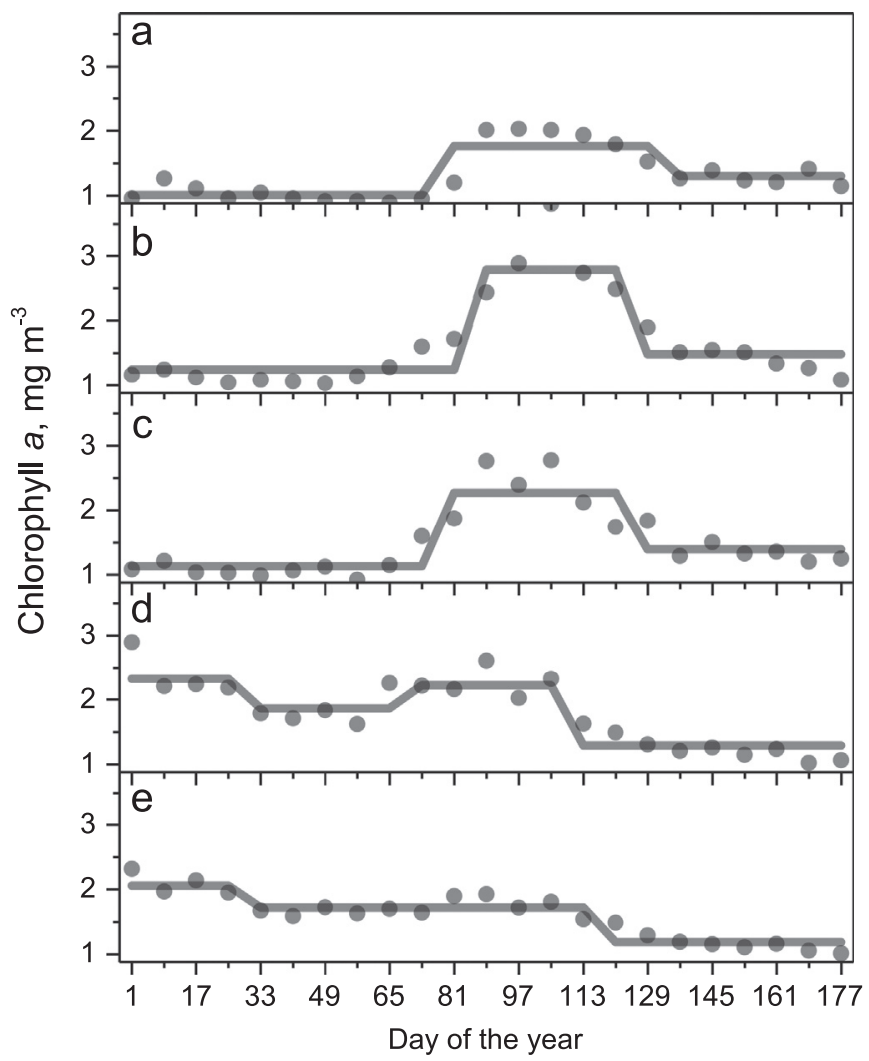

Fig. 2. Points depict smoothed (3-point moving averages) of time series (19982013) mean chlorophyll-a concentrations for the first half of the year by production unit. Lines are STARS algorithm fit for each production unit. (a) Gulf of Maine East (b) Gulf of Maine West, (c) Georges Bank, (d) Middle Atlantic Bight North and (e) Middle Atlantic Bight South.

northern flank of the Bank had frequencies of 0.8 whereas the southern flank had frequencies $<0.6$ indicating that the spring bloom was not always a discernible event in that area.

The mean start day of the year of the spring bloom increased from south to north spanning a period of approximately 60 days. The earliest spring blooms occurred in the southern end of the Middle Atlantic Bight around day 50 or near the end of February (Fig. 3b). Through much of the Middle Atlantic Bight and Georges Bank, the spring bloom started closer to day 80 (mid-March). Mean bloom start day increased in an east to west gradient across the Gulf of Maine; spring bloom tended to start around day 100 or during early April in the northern portion of the Gulf of Maine.

Across all production units, bloom magnitude was generally greatest close to the coast. The largest magnitude blooms tended to occur in the Gulf of Maine and on Georges Bank. Bloom magnitudes exceeded $15 \mathrm{mg} \mathrm{m}^{-3} 8$-day in the southern segments of the Gulf of Maine, along much of the Gulf of Maine coast, the northern flank of Georges Bank, and in Nantucket Shoals (Fig. 3c). Bloom magnitudes were generally less than $10 \mathrm{mg} \mathrm{m}^{-3}$ 8-day over the balance of the ecosystem including the Middle Atlantic Bight, central and northern Gulf of Maine, and southern flank of Georges Bank.

The relationship between spring bloom start day and bloom magnitude for a given grid location were generally negative indicating that earlier blooms tended to be longer lasting and larger in magnitude. Inversely, late blooms tended to be shorter and lower in magnitude. The Pearson product-moment correlation analysis between start day and bloom intensity, duration, and magnitude was limited to grid locations with at least eight detected blooms (i.e., detectable blooms found in at least half the
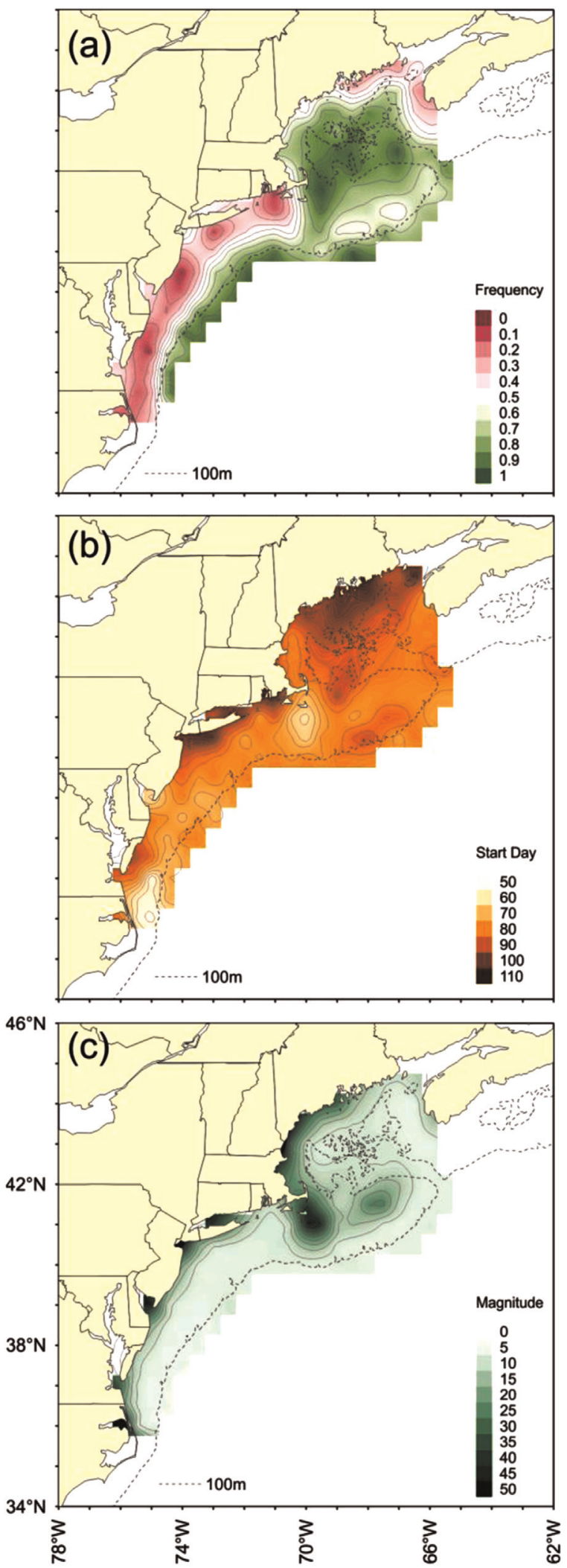

Fig. 3. Contour plots of spring bloom average frequency of occurrence (a, proportion), start day (b, day of the year), and bloom magnitude (c, $\mathrm{mg} \mathrm{m}^{-3} 8$-day) based on half degree gridded data over the period 1998-2013.

time series years). The correlation between start day and bloom intensity tended to be negative in most areas, however, the correlation field was relatively weak with only a few locations yielding significant correlations (Fig. 4a). The correlation between 

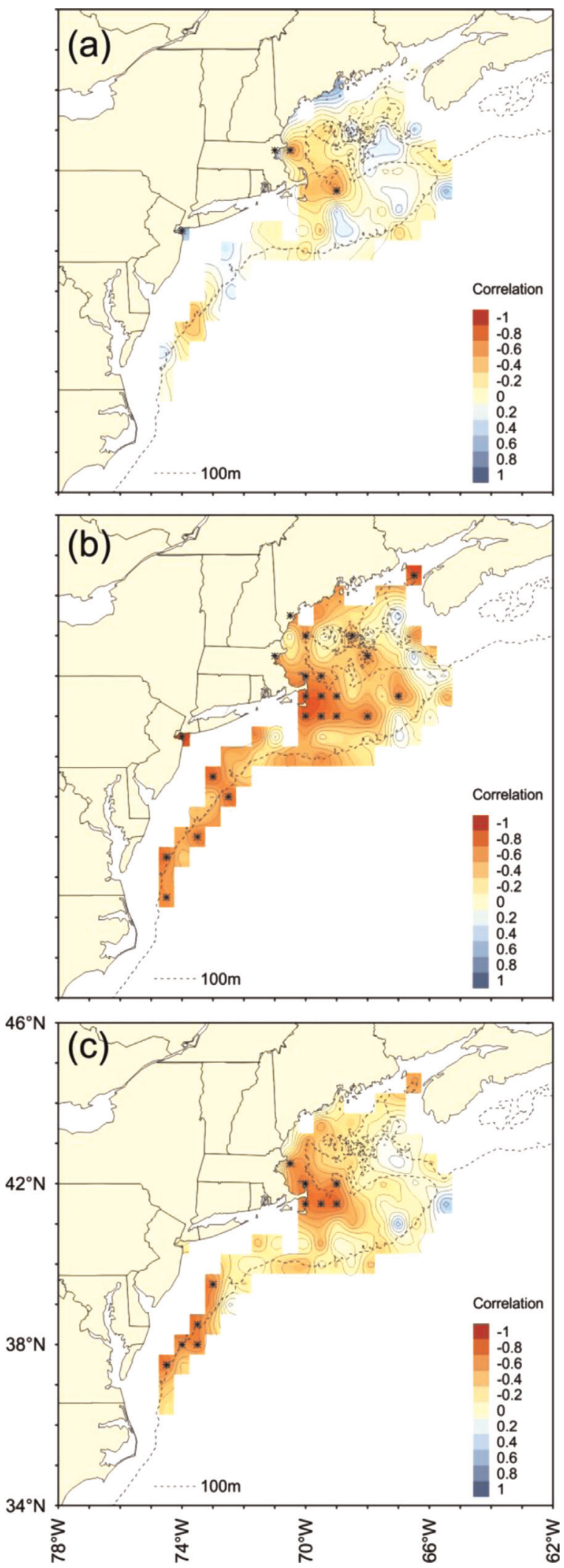

Fig. 4. Contour plots of Pearson product-moment correlation between start day and bloom intensity, duration and magnitude ( $a, b$, and c, respectively) based on half-degree gridded data over the period 1998-2013. Asterisks mark significant correlations at $p=0.05$.

start day and bloom duration was generally stronger than the intensity correlation field yielding many significant negative correlations in the western Gulf of Maine and the eastern margin of the

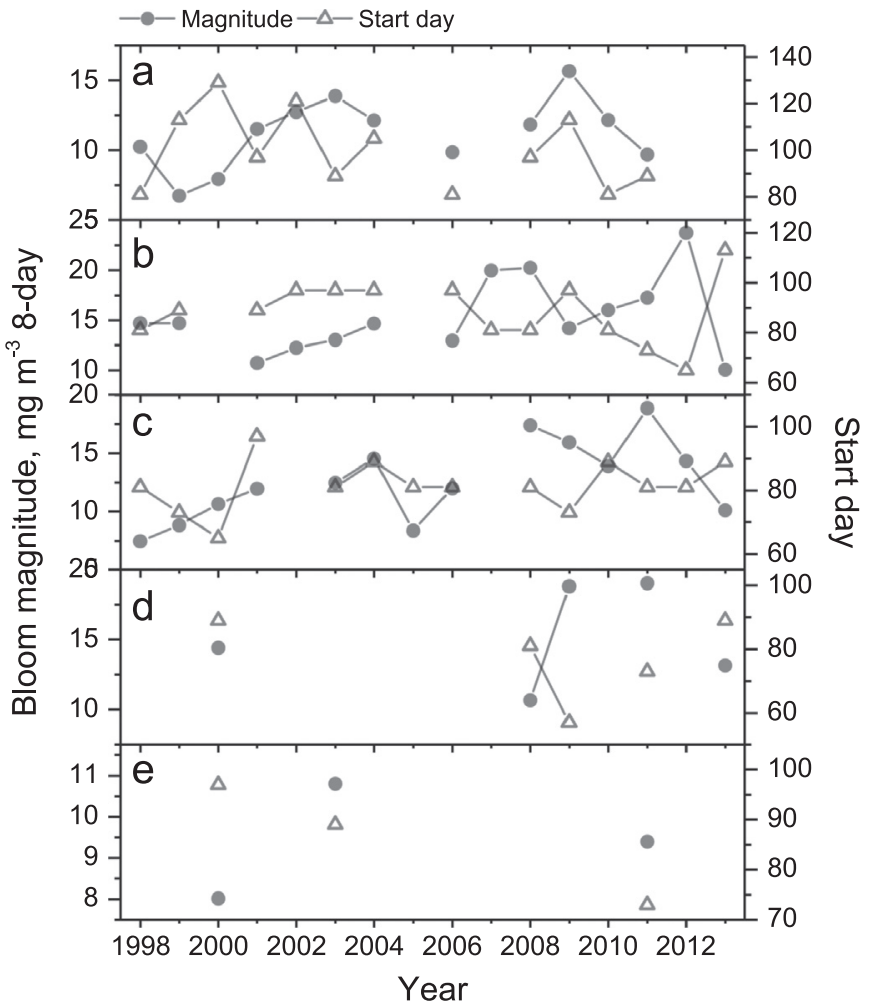

Fig. 5. Time series of bloom magnitude and start day by production units Gulf of Maine East (a) and West (b), Georges Bank (c), and Middle Atlantic Bight North (d) and South (e). (a) Gulf of Maine East, (b) Gulf of Maine West, (c) Georges Bank, (d) Middle Atlantic Bight North and (e) Middle Atlantic Bight South.

Middle Atlantic Bight (Fig. 4b). The correlation field between start day and bloom magnitude followed the same pattern as the correlation field based on the duration data, suggesting a larger role for bloom duration than intensity in defining the pattern of bloom magnitude (Fig. 4c).

\subsection{Production unit spring bloom analysis}

The analysis of spring bloom timing and magnitude by Northeast Shelf production units reflect the patterns observed in the gridded analysis and provide bloom statistics at a spatial scale that can be directly compared to spring zooplankton biovolume data. Spring bloom start day and bloom magnitude exhibited temporal variation in each of the Northeast Shelf production units, with some of the most extreme changes occurring in recent years. Mean start day was 100 (April 9) for detected blooms in the eastern Gulf of Maine unit, and mean bloom magnitude was $11.2 \mathrm{mg} \mathrm{m}^{-3} 8$-day (Fig. 5a). The largest bloom magnitude for the eastern Gulf of Maine was observed in 2009 in excess of $15 \mathrm{mg} \mathrm{m}^{-3} 8$-day. Start day in the western Gulf of Maine, which has averaged day 82 (March 22) over the time series, has varied more systematically over time following a trend of earlier blooms over the past decade to an early date of 65 (March 5) with the exception of the 2013 bloom which started on day 113 (April 22) (Fig. 5b). The 2012 western Gulf of Maine detected bloom was the earliest in the time series and the 2013 was latest detected bloom with a positive change-point on day 113 (April 22). Western Gulf of Maine bloom magnitude averaged $15.3 \mathrm{mg} \mathrm{m}^{-3}$ 8-day for detected blooms; the detected bloom in 2013 was the lowest magnitude bloom in the time series. There were detected blooms in most years for the Georges Bank unit, which contrasts to the bloom frequency observed in the gridded analysis. Georges Bank blooms had an 


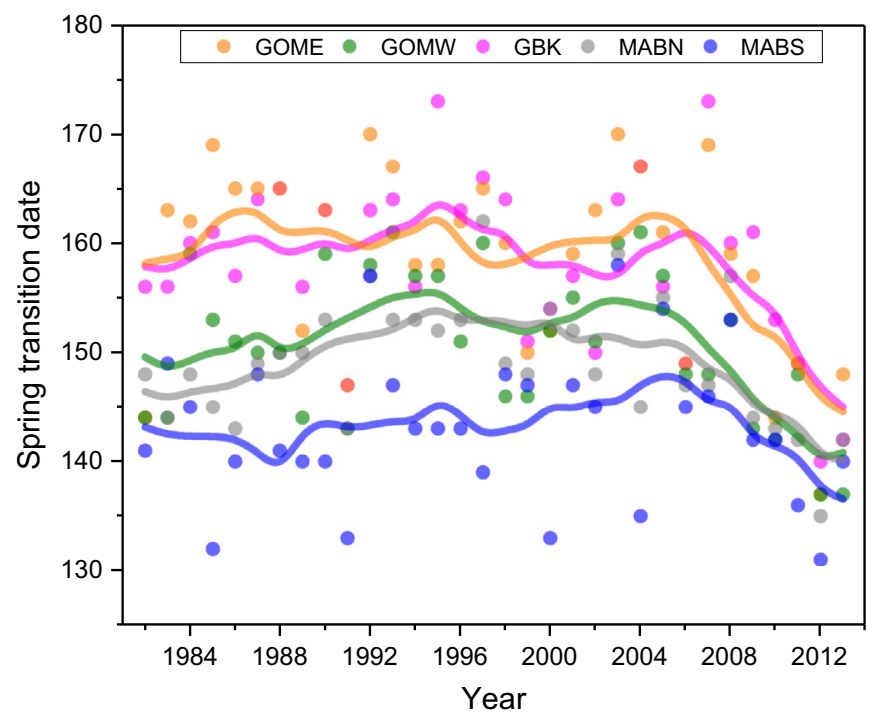

Fig. 6. Time series of spring transition date by production units Gulf of Maine East (GOME) and West (GOMW), Georges Bank (GBK), and Middle Atlantic Bight North (MABN) and South (MABS). Lines are a seven point adjacent average smoother.

average start day of 81 (March 21) and magnitude of $12.6 \mathrm{mg} \mathrm{m}^{-3}$ 8-day (Fig. 5c). There were low numbers of blooms detected in the Middle Atlantic Bight; the blooms in the northern Middle Atlantic Bight were of higher magnitude than the blooms in the southern Middle Atlantic Bight (Fig. 5d and e).

\subsection{Spring thermal transition and bloom start}

Spring thermal transition date has changed most dramatically in recent years advancing nearly two weeks in all production units. The transition temperatures for the production units used in the analysis were $9.1,10.3,11.2,13.0$, and $15.4{ }^{\circ} \mathrm{C}$ for eastern and western Gulf of Maine, Georges Bank, and northern and southern Middle Atlantic Bight, respectively. The average spring transition date was June 8 in the eastern Gulf of Maine and Georges Bank production units during the first two and half decades of the time series (Fig. 6). Since 2006, transition date advanced by 19 days in these units, which exhibited the greatest change in transition date among the production units. The mean transition dates during the first segment of the time series for the western Gulf of Maine was May 31; the spring transition advanced in this area by about two weeks since 2006. The least amount of change in spring transition occurred in the Middle Atlantic Bight units, which only advanced by 12 days since 2006 .

Spring transition date appears to have had a significant effect on spring bloom timing in the western Gulf of Maine. The correlation between start day and spring transition day was 0.68 $(p<0.01)$ for detected blooms in that unit (Fig. 7). Correlation between start day and spring transition day was non-significant in the Georges Bank. The absence of correlation in the eastern Gulf of Maine Shelf and Middle Atlantic Bight should be interpreted in the context of the low number of detected blooms in these areas.

\subsection{Production unit zooplankton biovolume}

Spring zooplankton biovolume differed among Northeast Shelf production units and exhibited a high degree of inter-annual variation. Spring zooplankton biovolume was highest in the Georges Bank unit averaging $\approx 1.7 \log \mathrm{cm}^{3} \mathrm{~m}^{-3}$ (Fig. 8c). The lowest spring biovolumes were observed in the northern and southern ends of the ecosystem; spring zooplankton biovolume averaging $\approx 1.2$ to $1.3 \log \mathrm{cm}^{3} \mathrm{~m}^{-3}$ in the eastern Gulf of Maine and southern Middle Atlantic Bight units, respectively (Fig. 8a and e). Biovolume averaged $\approx 1.4 \log \mathrm{cm}^{3} \mathrm{~m}^{-3}$ in the western Gulf of Maine and northern Middle Atlantic Bight production units (Fig. 8b and d).

\subsection{Relationships between chlorophyll, bloom indices, and zoo- plankton biomass}

Winter chlorophyll concentrations were not related to spring zooplankton biovolume in any production unit. The highest correlation between spring zooplankton biovolume and winter chlorophyll concentration was observed in the northern Middle Atlantic Bight unit; however, that negative correlation was not significant (Fig. 9d). Correlations were lower in the other units (Fig. 9).

Proximate month chlorophyll concentration was significantly correlated with spring zooplankton biovolume in Georges Bank and southern Middle Atlantic Bight production units; however, the sign of these correlations were not consistent among units. Proximate month chlorophyll concentration was positively correlated with zooplankton biovolume on Georges Bank (Fig. 10c); this correlation is in contrast to a negative correlation between proximate month chlorophyll concentration and zooplankton biovolume in the southern Middle Atlantic Bight (Fig. 10e). The correlations in the other production units were non-significant (Fig. 10).

Spring zooplankton biovolume was significantly correlated with bloom timing and magnitude in the western Gulf of Maine production units and with bloom intensity on Georges Bank. Spring bloom start day, intensity, and magnitude were not correlated with zooplankton biovolume in the eastern Gulf of Maine unit using either measure of zooplankton biovolume (Fig. 11a-c). Western Gulf of Maine biovolume was positively correlated with bloom start and negatively correlated with bloom magnitude (Fig. 11d and f); bloom intensity was uncorrelated with biovolume in this unit (Fig. 11e). As in the eastern Gulf of Maine, either measure of zooplankton biovolume provided equivalent results. Bloom intensity was positively correlated to biovolume on Georges Bank while the bloom start day and magnitude were uncorrelated (Fig. 11g-i).

The correlations between zooplankton biovolume, chlorophyll concentrations, and bloom indices should be conditioned on the relative range and contrast in these data. Two significant correlations between zooplankton biovolume and proximate chlorophyll concentrations were observed; however, these correlations were of differing signs. The negative correlation in the southern Middle Atlantic Bight was based on chlorophyll concentration data that had the smallest inter-quartile range of any production unit (Fig. 12a). In contrast, the positive correlation on Georges Bank was associated with the largest inter-quartile range of these data. Significant correlations between zooplankton biovolume and bloom parameters were found in two production units. Zooplankton biomass was related to the intensity of the bloom on Georges Bank, which is a redundant test of the correlation between zooplankton biovolume and proximate chlorophyll concentrations. Zooplankton biomass was related to the timing and magnitude of the spring bloom in the western Gulf of Maine. Low zooplankton biomass was associated with early, large magnitude blooms, whereas high zooplankton biomass was associated with late, small magnitude blooms. Zooplankton biovolume in this production unit was not related to bloom intensity or proximate chlorophyll concentration as is the case on Georges Bank. These correlations can be better evaluated by examining the bloom conditions on Georges Bank and western Gulf of Maine in a comparative fashion. The proximate chlorophyll in western Gulf of Maine was high in most years and not as variable as on Georges 


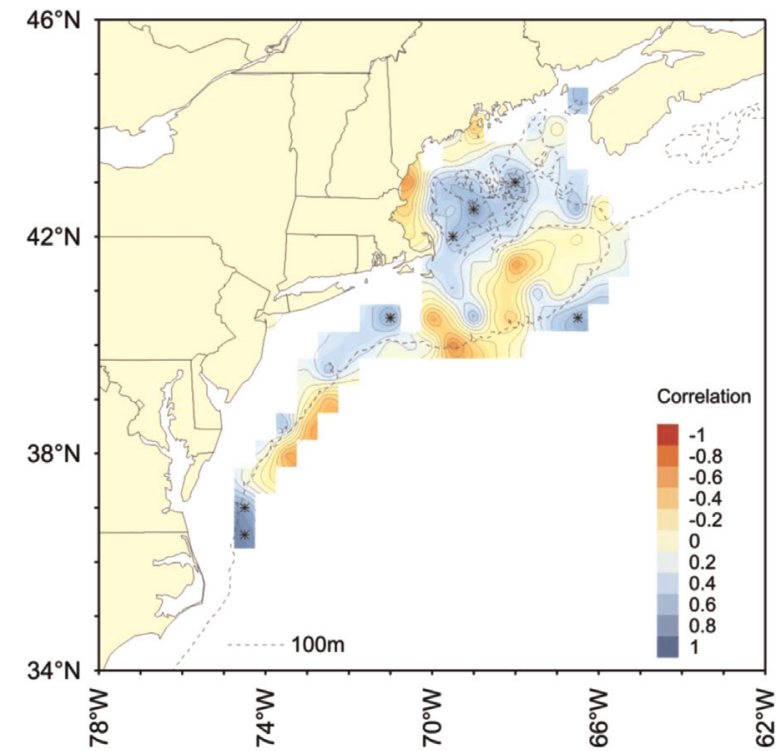

Fig. 7. Contour plots of Pearson product-moment correlation between spring transition date and bloom start day based on half-degree gridded data over the period 1998-2013. Asterisks mark significant correlations at $p=0.05$.

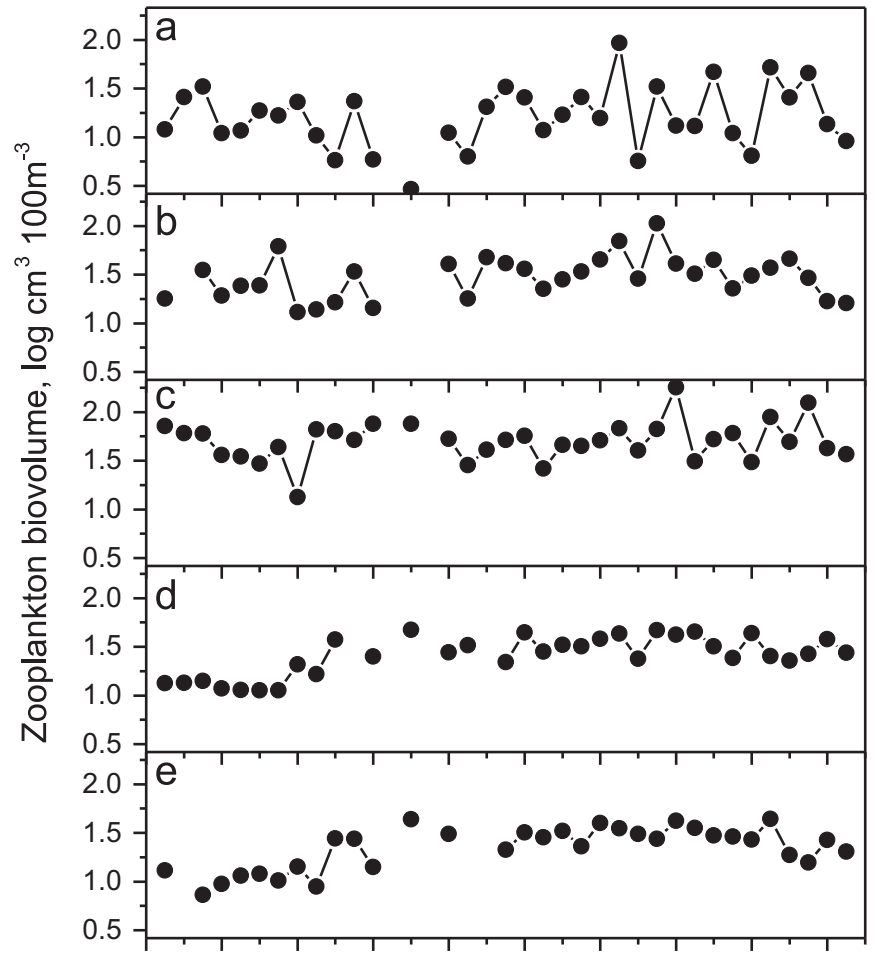

1976198019841988199219962000200420082012

Year

Fig. 8. Time series of zooplankton biovolume by production unit. (a) Gulf of Maine East, (b) Gulf of Maine West, (c) Georges Bank, (d) Middle Atlantic Bight North and (e) Middle Atlantic Bight South.

Bank (Fig. 12a). As noted, the western Gulf of Maine blooms started over a wide range of start days, whereas the Georges Bank bloom started over a more limited range of dates (Fig. 12b).

\subsection{Zooplankton taxa associated with biovolume}

The numerical abundance of several zooplankton taxa were significantly and positively correlated with zooplankton biovolume. Abundance of the copepod Oithona spp. was significantly correlated with biovolume in all five Northeast Shelf production units (Table 1 ). Two other taxa, C. finmarchicus and copepoda, unidentified copepods, were significantly correlated in four of the five units. The copepods Centropages typicus and $\mathrm{Me}$ tridia lucens were significantly correlated in three of the units. Of these taxa, $C$. finmarchicus had the highest average abundance or was among the highest abundance in all five units; it was also one of the largest zooplankton taxa occurring on the Northeast Shelf (Fig. 13a-e). The other highly correlated copepod taxon, Oithona spp., tended to be of relatively moderate abundance and is one of the smallest copepod taxa, which suggests its abundance trends likely correlate with $C$. finmarchicus abundance and makes less of a contribution to observed biovolumes. M. lucens is one of the larger copepod species on the Northeast Shelf and was found to be of moderate abundance, thus likely contributing to biovolume. The most abundant copepod taxon in the Middle Atlantic Bight, C. typicus, was highly correlated to biovolume in those areas. One of the most abundant taxa in all shelf production units, Pseudocalanus spp., was found to be correlated with biovolume in the eastern Gulf of Maine and northern Middle Atlantic Bight.

\section{Discussion}

The spring bloom is not uniformly developed over the entirety of the Northeast Shelf ecosystem; thus it has different ecological meaning in different sub-regions. The bloom dynamics of the northern production units of the Northeast Shelf contrast the dynamics of the Middle Atlantic Bight, which is fundamentally different owing to its geographic scope and cross-shelf extent. The spring bloom is a distinct event in the Gulf of Maine and Georges Bank that can be detected in most years and begins in March into April during most years. The Middle Atlantic Bight does not share the northern temperate characteristics of the Gulf of Maine, tends to be oligotrophic in some areas, has longer day length and lower solar zenith angle in winter than the Gulf of Maine, and exhibits greater inter-annual and seasonal changes in water temperatures. Because of these factors, it exhibits unique spring phytoplankton characteristics that made it difficult to differentiate a bloom from the high winter chlorophyll concentrations typical of the region (Xu et al., 2011). Near the offshore boundary of the Middle Atlantic Bight, high levels of winter chlorophyll may reflect this region's similarity to subtropical conditions (i.e. light levels, winds), since the North Atlantic subtropical gyre is characterized by an OctoberFebruary chlorophyll maximum (Henson et al., 2009; Siegel et al., 2002). Hence, in some years, blooms in the Middle Atlantic Bight were detected with start dates as early as February.

Sub-regional variability in phytoplankton phenology is not unusual and has been observed in the California Current System (Henson and Thomas, 2007), the subarctic North Pacific (Sasaoka et al., 2011), and the Southern Ocean (Thomalla et al., 2011). This variability likely reflects both enduring climatological differences within regions and transient, localized processes, such as storms, mesoscale eddies, horizontal advection of distinct water masses, tidal mixing and bathymetry (Greene et al., 2012; Mahadevan et al., 2012; McGillicuddy et al., 2007). Finally, our analysis compares well to the seasonal averages described for the Gulf of Maine by Thomas et al. (2003) and differ from the descriptions of bloom initiation in Ji et al. (2007) and Song et al. (2010) because their study domains extended further north and eastward over the shallower areas of the Scotian Shelf.

In parts of the ecosystem where the spring bloom consistently develops each year, the time schedule of spring warming appears to be an important factor in the initiation of the bloom. Though warming appears to contribute to the timing of the spring bloom, 


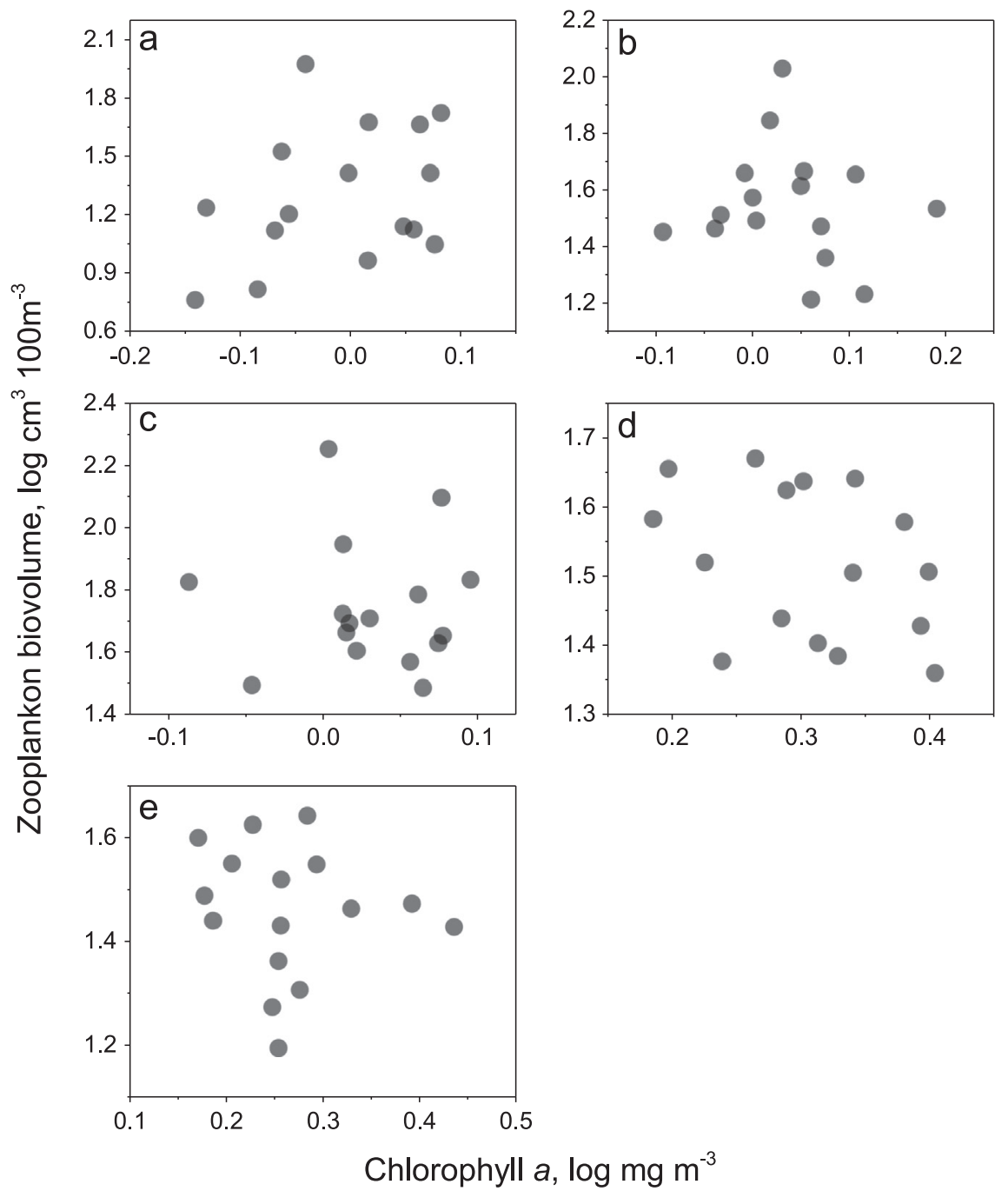

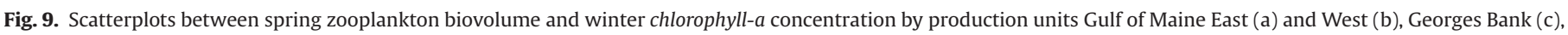
and Middle Atlantic Bight North (d) and South (e). (a) r=.34, $\mathrm{P}=.20$, (b) $r=-.12, \mathrm{P}=.65$, (c) r=-.02, $\mathrm{P}=.93$, (d) $\mathrm{r}=-.35, \mathrm{P}=.19$ and (e) $\mathrm{r}=-.13$, $\mathrm{P}=.63$.

water column stratification and critical depth are more proximate factors affected by thermal (wind) conditions and affect density (convective) driven mixing (Ji et al., 2008; Taboada and Anadon, 2014; Townsend et al., 1992). Furthermore, Song et al. (2010) associated the start of the bloom with the surface salinity anomaly in April, with a later spring bloom observed when surface salinity in April was high. Also in the previous work by Song et al. (2010), nutrient levels were shown to exert control over bloom magnitude in the Gulf of Maine independently of bloom timing. We did not retest the effect of nutrient levels on bloom dimension, but do introduce the potential effect of grazing on bloom dimension, which we believe is functioning as a modifier of bloom dynamics synergistically with nutrient availability (Behrenfeld and Boss, 2014).

We found that early spring blooms were associated with larger bloom magnitudes in several regions, mainly due to the extended bloom duration. The relationship between the timing, duration, and magnitude of the spring bloom has not been previously investigated to any great degree, although a few studies have briefly noted a linkage between these bloom characteristics. Similar to the results of our research, Song et al. (2011), Henson et al. (2009), and Racault et al. (2012) observed weak correlations between bloom start dates and bloom magnitude and duration across parts of the North Atlantic. In the Sea of Japan, long lasting phytoplankton blooms were also associated with increased rates of annual primary productivity (Yamada and Ishizaka, 2006). Early blooms in the Gulf of Maine may be particularly long lived due to the fact they tend to occur in colder water, which is associated with slower rates of phytoplankton growth and zooplankton responses (Song et al., 2011).

Variation in bloom timing and duration may reflect a phenological mismatch between bloom development and zooplankton grazing and thus the "top-down" control of bloom termination. It appears that late blooms are better synchronized with the developing zooplankton community. The emergence of zooplankton from benthic habitats may be affected by differing spring warming schedules (Mackas et al., 2012) than phytoplankton, which are affected by events in the euphotic zone and surface warming. The entry of $C$. finmarchicus diapause has been hypothesized to be controlled by the amount of lipid accumulated prior to diapause (Johnson et al., 2008); while the duration and exit of $C$. finmarchicus diapause is mainly controlled by bottom temperature-dependent metabolic depletion rate of lipid (Saumweber and Durbin 2006; Pierson et al. 2013) (Pierson et al., 2013; Saumweber and Durbin, 2006). Surface temperature at onset of diapause is a better proxy of diapause duration than winter/spring temperature (Johnson et al., 2008). Thus, an earlier spring surface warming may influence phytoplankton phenology more than that of their zooplankton grazers. Johnson et al. (2006) state that $C$. finmarchicus in the Gulf of Maine emerge from dormancy as early as late 


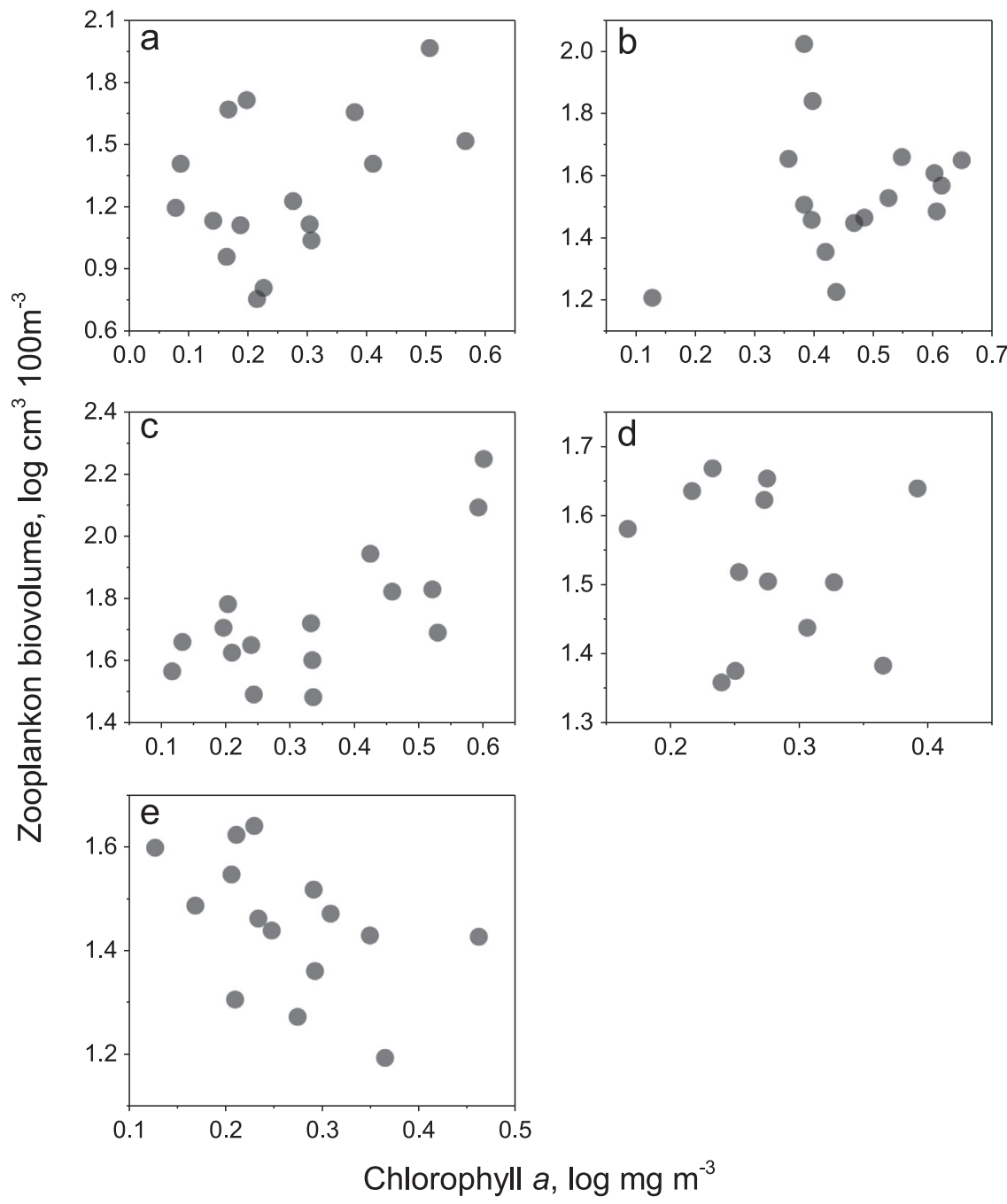

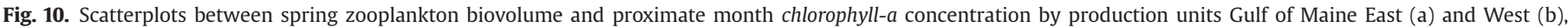
Georges Bank (c), and Middle Atlantic Bight North (d) and South (e). (a) r=.43, P=.10, (b) r=.25, P=.36, (c) r=.71, P <.01, (d) r=-.34, P=.20 and (e) r=-.49, P=.05.

December. Thus, emerging copepods would have been able to also take advantage of an early bloom. Indeed, Durbin et al. (2003) demonstrated that when chlorophyll concentration was high in February, C. finmarchicus egg production rates were higher and more early stages copepodites were present. Thus, rather than differences between the timing of diapause exit and phytoplankton phenology, it may be variability between zooplankton population development and phytoplankton phenology that leads to the observed differences in bloom magnitude. We propose that when the phytoplankton bloom is late, zooplankton populations have sufficient time to develop, so the grazing pressure on phytoplankton increases, resulting in a smaller bloom. An analysis of stage distribution of zooplankton populations over different bloom dynamics may shed further light on this proposed mechanism.

The structure of our datasets permitted us to consider a number of hypotheses concerning the effect of the spring bloom on spring zooplankton biovolume. The data for Georges Bank supports the hypothesis that variation in chlorophyll concentration affects biovolume directly given that the spring bloom generally begins at the same time each year and that there is significant contrast in the range of chlorophyll concentration for that area. For this region, we saw that low proximate (April) chlorophyll concentration was associated with low zooplankton biovolume and vice versa for high chlorophyll concentration. This relationship was also seen in the correlation between spring bloom intensity and biovolume and is suggestive of a dominant "bottom-up" influence on the zooplankton population. The association between proximate phytoplankton concentration and zooplankton biovolume may have been further enhanced in Georges Bank because the zooplankton community tends to be dominated by small species, which are faster growing (Hansen et al., 1997), and may quickly build up their population in response to increases in phytoplankton. In contrast, for the western Gulf of Maine we observed an inverse relationship between mesozooplankton biovolume and bloom timing and magnitude suggestive of a "top-down" mechanism of control and another hypothesis. If low zooplankton biovolume is taken as potential for lower zooplankton grazing, it would appear that years with lower zooplankton biovolume tended to have phytoplankton blooms that were of longer duration and larger magnitude. This line of reasoning provides no explanation for the absence of a relationship between bloom intensity and biovolume in this area and is inconsistent with the observation that bloom timing appears to explain bloom duration. These inconsistencies suggest another "bottom-up" influence may be at work.

Whereas it is clear to understand the functional relationship between food quantity and the biomass of predators, in this case the quantity of phytoplankton and zooplankton biovolume (Steinberg et al., 2012), it is less clear to understand the effect of bloom timing on zooplankton biomass. Zooplankton engage in a 


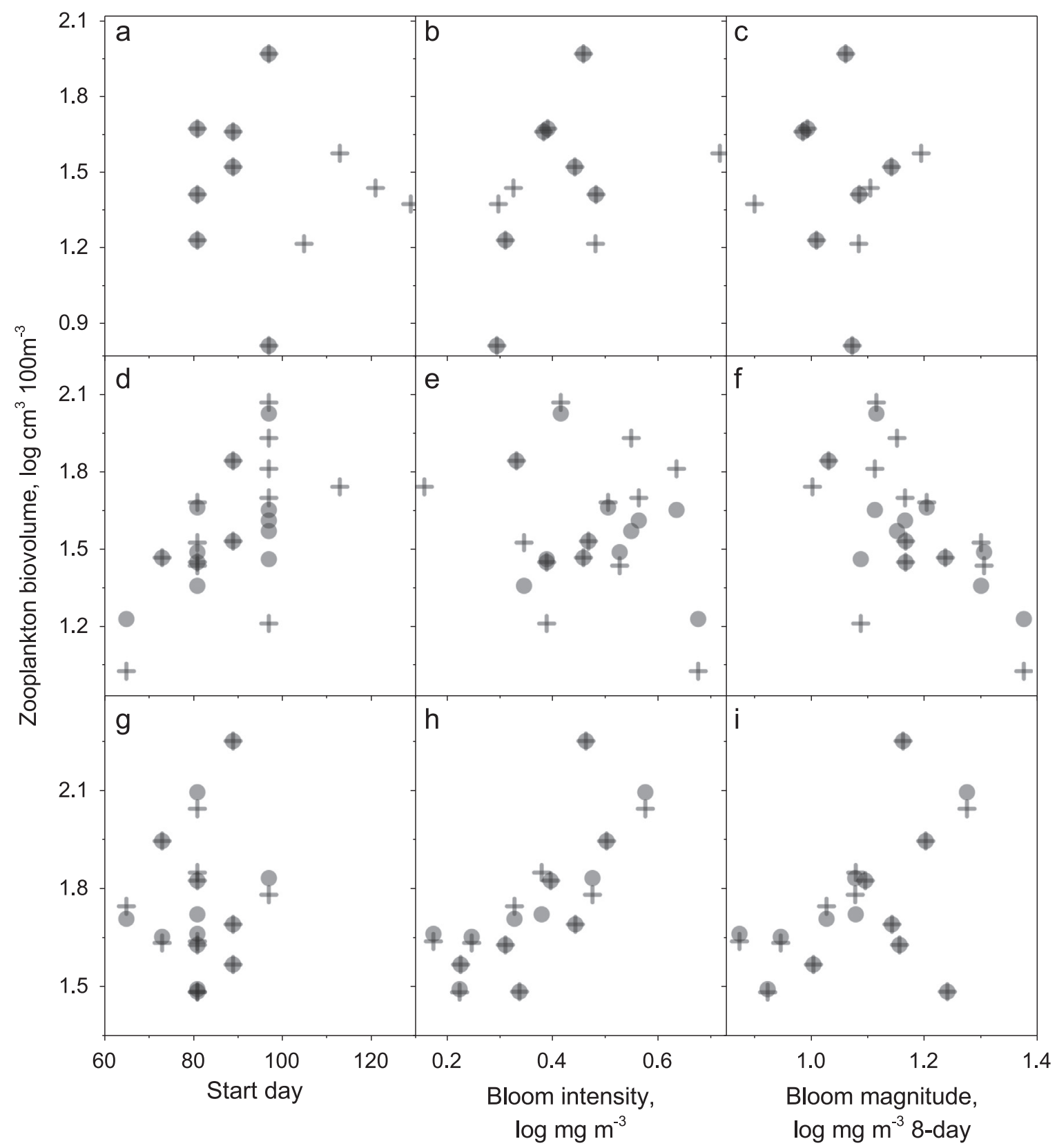

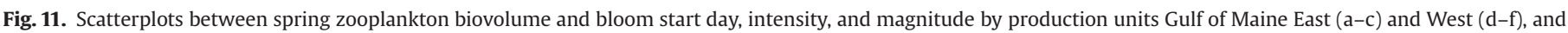

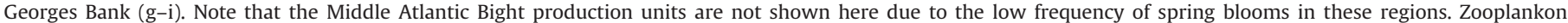

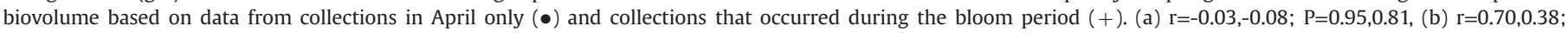

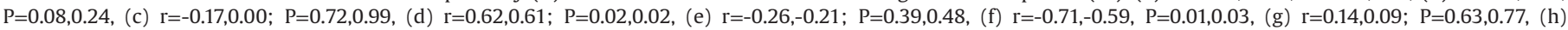
$r=0.76,0.75 ; P<0.01,0.01$ and $(i) r=0.48,0.48 ; P=0.08,0.08$

range of selective feeding behaviors, but what may be a universal aspect of zooplankton feeding is the relationship between ingestion rate and food density (Gamble, 1978; Isari et al., 2013; Leiknes et al., 2014). Demonstrative differences in phytoplankton biomass or particle density will likely result in differences in ingestion rate and accumulated zooplankton biovolume. This concept provides a mechanistic underpinning for the phenomenon observed on Georges Bank. Bearing in mind that chlorophyll is an imperfect indicator of phytoplankton biomass, alternative "bottom-up" factors such as the effect of food size and quality may come to the fore. For the phenomenon we observed in western Gulf of Maine, we can focus on how change in bloom timing may affect the size and quality of phytoplankton in the context of zooplankton feeding and trophic transfer, while at the same time providing little inter-annual contrast in chlorophyll concentration. Bloom start date would likely result in different species assemblages that constitute the spring bloom each year (Dakos et al., 2009; Irigoien et al., 2000). The timing may also influence the size spectra and species composition of the bloom due to the effects of thermal conditions when the bloom develops (Barnes et al., 2011; Mousing et al., 2014) or due to the light regime affecting early versus late blooms (Polimene et al., 2014). We can suggest a number of mechanistic hypotheses of how bloom start might have affected the nutritional value of the spring phytoplankton available to zooplankton predators in western Gulf of Maine. Collectively, our data and other studies suggest that multiple factors associated with the spring bloom can synergistically impact zooplankton biovolume and thus have consequences for energy flow in the ecosystem. 


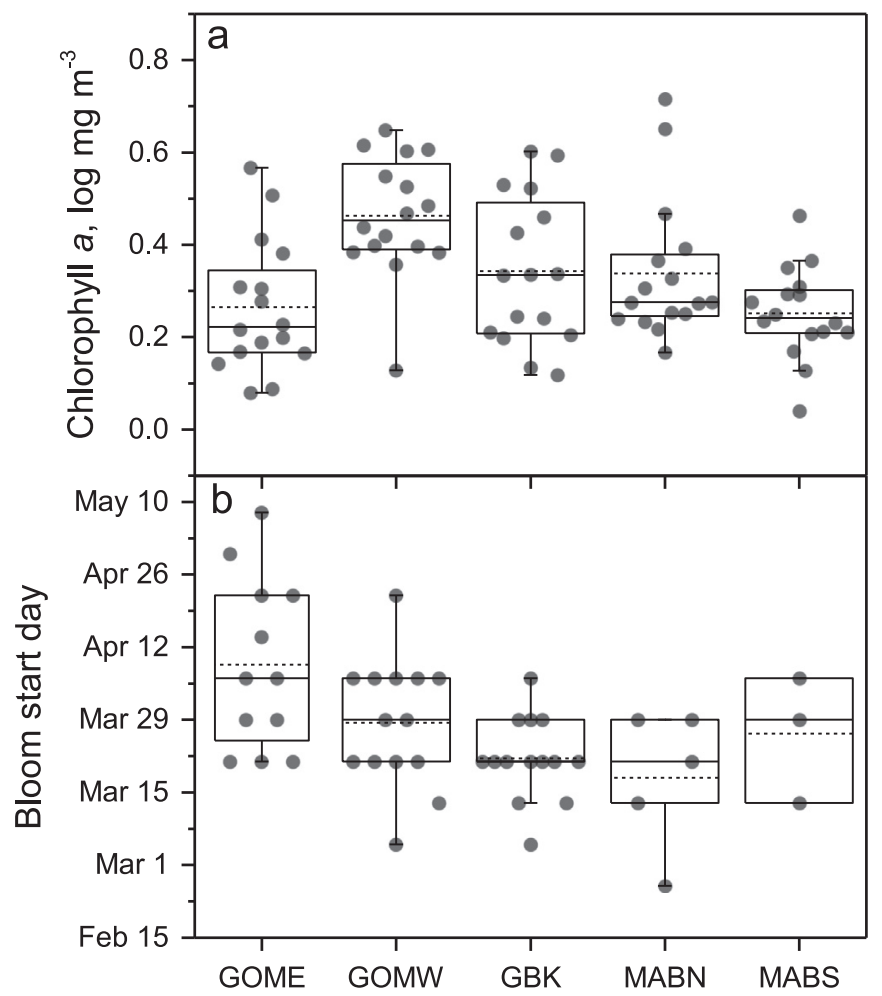

Fig. 12. Box plots with data overlaid of proximate chlorophyll-a concentration (a) and bloom start day (b) for the Gulf of Maine East (GOME) and West (GOMW), Georges Bank (GBK), and Middle Atlantic Bight North (MABN) and South (MABS). Dashed lines denote means.

We consider it worthwhile to reverse the argument and consider the "top-down" effects of zooplankton on the development and fate of the spring bloom. We found that early, long duration spring blooms in the western Gulf of Maine were associated with lower zooplankton biomass. Clearly these larger dimension blooms did not transfer energy to zooplankton concomitant with their size. Thus, we hypothesize that early blooms occur before zooplankton can utilize them, perhaps owing to the timing of stage diapause, and go un-grazed to some degree. Early, un-grazed blooms result in high concentrations of phytoplankton biomass in the water column, which we suggest intensifies the rate of benthic flux (Wassmann, 1998). Late, sufficiently grazed blooms would then appear to transfer energy to zooplankton populations as reflected by the associated increase in biomass, and in turn shunt energy into pelagic food webs instead of benthic webs. Zooplankton performs a critical ecosystem function by transferring energy from phytoplankton to upper trophic levels, thus changes in zooplankton biomass could have important ecological consequences. For instance, an early spring bloom in the Gulf of Maine may be detrimental to upper trophic levels, as zooplankton biomass in the Gulf of Maine has been observed to influence a variety of pelagic consumers such as fish and whales (Darbyson et al., 2003; Friedland et al., 2013; Heath and Lough, 2007; Pershing et al., 2009). However, the early blooms would be expected to provide increased energy flux to benthic resources such as benthic feeding fish and invertebrates (Kirby et al., 2008; Woodland and Secor, 2013).

There are numerous examples of where even small shifts in the timing of production level can result in very large changes in the terminal disposition of the production resources (Parsons, 1988). In the Bering Sea, this shift in timing is actuated by the ice retreat, which results in an ecosystem shift between "top-down" and "bottom-up" forcing and has been termed the Oscillating Control Hypothesis (Hunt et al., 2002; Hunt and Stabeno, 2002). The
Table 1

Pearson product-moment correlation between zooplankton abundance and biovolume for spring tows during the period 1977-2013 by Northeast Shelf production units.

\begin{tabular}{|c|c|c|c|c|c|}
\hline Taxa & Georges Bank & $\begin{array}{l}\text { Gulf of } \\
\text { Maine } \\
\text { East }\end{array}$ & $\begin{array}{l}\text { Gulf of } \\
\text { Maine } \\
\text { West }\end{array}$ & $\begin{array}{l}\text { Middle } \\
\text { Atlantic } \\
\text { Bight } \\
\text { North }\end{array}$ & $\begin{array}{l}\text { Middle } \\
\text { Atlantic } \\
\text { Bight } \\
\text { South }\end{array}$ \\
\hline Oithona spp. & $0.516^{\text {*** }}$ & $0.644^{* * * *}$ & $0.532^{* *}$ & $0.764^{* *}$ & $0.633^{\text {**⿰冫⿰亅⿱丿丶丶 }}$ \\
\hline Copepoda & $0.548^{* * *}$ & $0.646^{* * *}$ & $0.566^{\text {**k }}$ & $0.564 * *$ & 0.218 \\
\hline $\begin{array}{l}\text { Calanus } \\
\text { finmarchicus }\end{array}$ & 0.286 & $0.695 * *$ & $0.467^{* * *}$ & $0.445^{*}$ & $0.359^{*}$ \\
\hline $\begin{array}{l}\text { Centropages } \\
\text { typicus }\end{array}$ & 0.053 & $0.559 * *$ & -0.135 & 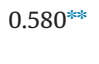 & $0.821 * *$ \\
\hline Metridia lucens & 0.103 & $0.556^{* * *}$ & 0.287 & $0.353^{*}$ & $0.446^{*}$ \\
\hline $\begin{array}{c}\text { Clausocalanus } \\
\text { arcuicornis }\end{array}$ & $0.465^{*}$ & & $0.576^{* * *}$ & $0.536^{* * *}$ & \\
\hline Sagitta spp. & 0.173 & $0.553^{* *}$ & & $0.422^{*}$ & $0.413^{*}$ \\
\hline $\begin{array}{l}\text { Pseudocalanus } \\
\text { spp. }\end{array}$ & 0.200 & $0.501^{* * *}$ & 0.125 & $0.483^{* *}$ & -0.185 \\
\hline $\begin{array}{l}\text { Temora } \\
\text { longicornis }\end{array}$ & & & -0.074 & $0.768 * *$ & $0.591 * *$ \\
\hline Harpacticoida & $0.742^{* * *}$ & $0.693^{* *}$ & & & \\
\hline $\begin{array}{l}\text { Microcalanus } \\
\text { spp. }\end{array}$ & $0.532^{*}$ & $0.791^{* * *}$ & $0.683^{* * *}$ & & \\
\hline $\begin{array}{c}\text { Centropages } \\
\text { hamatus }\end{array}$ & -0.150 & & -0.096 & $0.463^{\text {*** }}$ & 0.199 \\
\hline Appendicularia & 0.211 & $0.466^{* * *}$ & 0.149 & 0.132 & -0.044 \\
\hline Ophiuroidea & 0.214 & & 0.268 & $0.487^{*}$ & \\
\hline Polychaeta & & & $0.395^{*}$ & & \\
\hline Euchaetidae & & $0.563^{* * *}$ & 0.209 & & \\
\hline Euphausiacea & & & 0.155 & & 0.167 \\
\hline Balanidae & 0.173 & 0.303 & -0.057 & 0.271 & 0.108 \\
\hline
\end{tabular}

* Correlations significant at $p=0.05$.

** Correlations significant at $p=0.01$.

consequences of this shift are profound as it affects the abundance of forage species and the recruitment of walleye Pollock (Theragra chalcogramma), a dominant predator in the system. Our expectations are that inter-annual variations in seasonal bloom timing on the Northeast Shelf will impact fisheries production (Song et al., 2011) and this is the pattern that is beginning to emerge as individual species are studied in greater detail (Leaf and Friedland, 2014).

Zooplankton biomass has at times been narrowly viewed as a $C$. finmarchicus index (Davis, 1984) and though this species is obviously a major contributor to zooplankton biomass, it is clear that many taxa contribute to the patterns of biomass seen on the Northeast Shelf. The medium-sized luminescent copepod $M$. lucens was significantly correlated to biomass trends throughout the northern half of the ecosystem. Its maximum abundance is measured in the Gulf of Maine, where increased primary productivity in winter has produced high abundance levels (Pershing et al., 2005). Though under-sampled in our nets, the interannual variability of the cyclopoid copepod Oithona spp. was similar to biomass patterns throughout ecosystem waters. These abundant and ubiquitous copepods are major contributors to total secondary production and exert strong grazing pressure on phytoplankton standing stocks (Gallienne and Robins, 2001). Biomass in the Middle Atlantic region was found to be strongly influenced by the abundance of the dominate copepod Centropages typicus. Reproductive rates of this robust species are closely linked to blooms of large phytoplankton, leading to the formation of large inshore concentrations during the spring season (Durbin and Kane, 2007). It is becoming increasingly clear that the population dynamics of several species needs to be considered to understand zooplankton production in marine ecosystems.

Though it is too early to draw conclusions, it is striking how extreme the bloom events were in the final years of the study time 


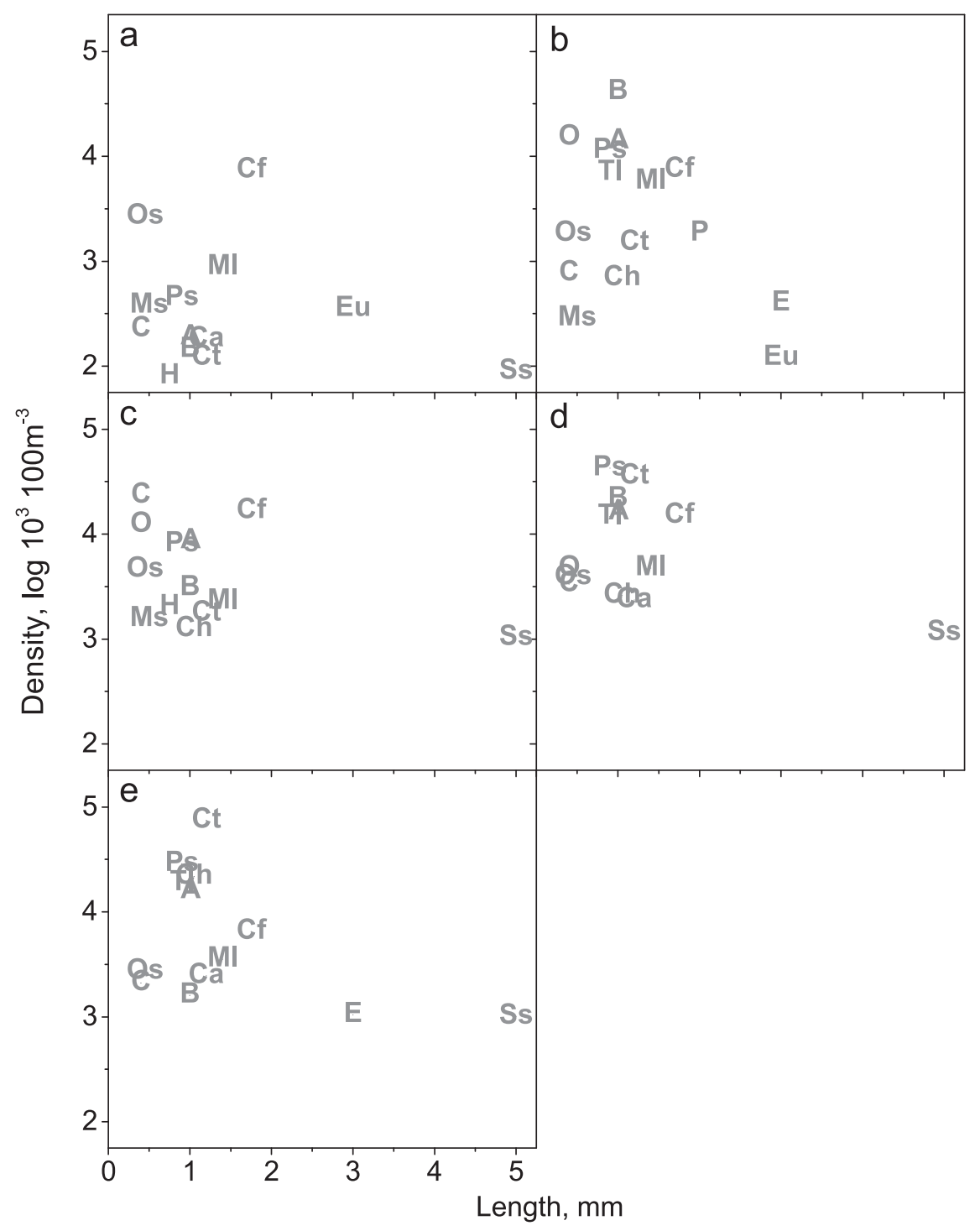

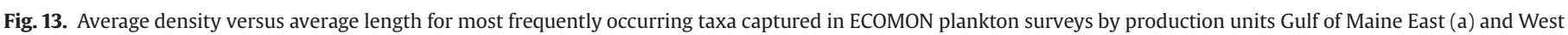

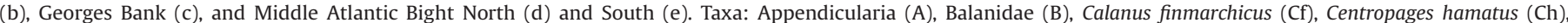

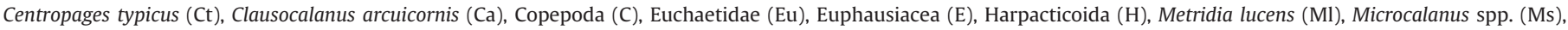

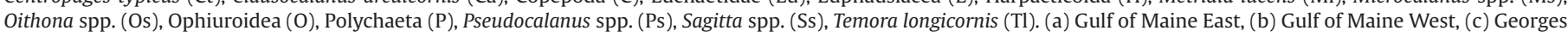
Bank, (d) Middle Atlantic Bight North and (e) Middle Atlantic Bight South.

series, particularly in the western Gulf of Maine. As demonstrated with our data on the shift in spring transition, the timing of physical events has shifted dramatically in the ecosystem. The Northeast Shelf ecosystem is experiencing wider swings in physical conditions (Mills et al., 2013) and biological responses, which would appear to reflect greater variation in the climate system impacting the ecosystem (Doney et al., 2012; Sydeman et al., 2013). There is an expectation that future climate conditions will impact bloom development in a number of different ways. Increasing winter temperature will likely impact the progression of spring stratification and may lead to less effective thermal convection, thus affecting the distribution of nutrients (Hordoir and Meier, 2012). Warming conditions may to an extent advance the timing of the spring bloom; however, the advance in timing will be constrained by the seasonal availability of light. Warming conditions may also shift the species composition of spring blooms from siliceous forms to species adapted to changing climate conditions (Sommer and Lengfellner, 2008; Winder and Sommer, 2012). Though there is an expectation that micro-zooplankton diversity, abundance, and trophic function will also change in response to climate change, the main focus of climate change impact studies has been on primary production, with less accomplished to date to evaluate the impact of climate on secondary production (Caron and Hutchins, 2013). The recent changes in the Northeast Shelf spring bloom are consistent with predictions of how climate will impact primary production; however, many aspects of the production cycle have yet to be examined in this context. We still need to know, among a long list of issues, how climate change and variability have been affecting bloom species composition and the ecosystem consequences of changing bloom timing and dimension.

\section{Acknowledgments}

We thank S. Ferreira and C. Melrose for comments on an earlier draft of the paper and J. Hare for assistance with zooplankton data. We also appreciate the collective efforts of the scientists that have 
contributed to the development of zooplankton time series, thus making this analysis possible.

\section{Appendix A. Supplementary material}

Supplementary data associated with this article can be found in the online version at http://dx.doi.org/10.1016/j.csr.2015.04.005.

\section{References}

Baier, C.T., Napp, J.M., 2003. Climate-induced variability in Calanus marshallae populations. J. Plankton Res. 25, 771-782.

Balch, W.M., Drapeau, D.T., Bowler, B.C., Booth, E.S., Goes, J.I., Ashe, A., Frye, J.M., 2004. A multi-year record of hydrographic and bio-optical properties in the Gulf of Maine: I. Spatial and temporal variability. Prog. Oceanogr. 63, 57-98.

Barnes, C., Irigoien, X., De Oliveira, J.A.A., Maxwell, D., Jennings, S., 2011. Predicting marine phytoplankton community size structure from empirical relationships with remotely sensed variables. J. Plankton Res. 33, 13-24.

Behrenfeld, M.J., Boss, E.S., 2014. Resurrecting the ecological underpinnings of ocean plankton blooms. Ann. Rev. Mar. Sci. 2014 (6), U167-U208.

Borstad, G., Crawford, W., Hipfner, J.M., Thomson, R., Hyatt, K., 2011. Environmental control of the breeding success of rhinoceros auklets at Triangle Island, British Columbia. Mar. Ecol. Prog. Ser. 424, 285-302.

Broms, C., Melle, W., 2007. Seasonal development of Calanus finmarchicus in relation to phytoplankton bloom dynamics in the Norwegian Sea. Deep-Sea Res. II: Top. Stud. Oceanogr. 54, 2760-2775.

Caron, D.A., Hutchins, D.A., 2013. The effects of changing climate on microzooplankton grazing and community structure: drivers, predictions and knowledge gaps. J. Plankton Res. 35, 235-252.

Chen, B., Zheng, L., Huang, B., Song, S., Liu, H., 2013. Seasonal and spatial comparisons of phytoplankton growth and mortality rates due to microzooplankton grazing in the northern South China Sea. Biogeosciences 10, 2775-2785.

Chiba, S., Aita, M.N., Tadokoro, K., Saino, T., Sugisaki, H., Nakata, K., 2008. From climate regime shifts to lower-trophic level phenology: synthesis of recent progress in retrospective studies of the western North Pacific. Prog. Oceanogr. 77, $112-126$.

Chiba, S., Saino, T., 2003. Variation in mesozooplankton community structure in the Japan/East Sea (1991-1999) with possible influence of the ENSO scale climatic variability. Prog. Oceanogr. 57, 317-339.

Chiswell, S.M., Bradford-Grieve, J., Hadfield, M.G., Kennan, S.C., 2013. Climatology of surface chlorophyll a, autumn-winter and spring blooms in the southwest Pacific Ocean. J. Geophys. Res.: Oceans 118, 1003-1018.

Chittenden, C.M., Jensen, J.L.A., Ewart, D., Anderson, S., Balfry, S., Downey, E., Eaves, A., Saksida, S., Smith, B., Vincent, S., Welch, D., McKinley, R.S., 2010. Recent salmon declines: a result of lost feeding opportunities due to bad timing? PLoS One, 5.

Cushing, D.H., 1990. Plankton production and year-class strength in fish populations - an update of the match mismatch hypothesis. Adv. Mar. Biol. 26, 249-293.

D'Ortenzio, F., Antoine, D., Martinez, E., d'Alcala, M.R., 2012. Phenological changes of oceanic phytoplankton in the 1980s and 2000s as revealed by remotely sensed ocean-color observations. Glob. Biogeochem. Cycles 26, 1-16.

Dagg, M.J., Turner, J.T., 1982. The impact of copepod grazing on the phytoplankton of Georges Bank and the New York Bight. Can. J. Fish. Aquat. Sci. 39, 979-990.

Dakos, V., Beninca, E., van Nes, E.H., Philippart, C.J.M., Scheffer, M., Huisman, J. 2009. Interannual variability in species composition explained as seasonally entrained chaos. Proc. R. Soc. B: Biol. Sci. 276, 2871-2880.

Darbyson, E., Swain, D.P., Chabot, D., Castonguay, M., 2003. Diel variation in feeding rate and prey composition of herring and mackerel in the southern Gulf of St Lawrence. J. Fish Biol. 63, 1235-1257.

Davis, C.S., 1984. Predatory control of copepod seasonal cycles on Georges Bank. Mar. Biol. 82, 31-40.

Doney, S.C., Ruckelshaus, M., Duffy, J.E., Barry, J.P., Chan, F., English, C.A., Galindo, H. M., Grebmeier, J.M., Hollowed, A.B., Knowlton, N., Polovina, J., Rabalais, N.N., Sydeman, W.J., Talley, L.D., 2012. Climate change impacts on marine ecosystems. Annu. Rev. Mar. Sci. 4, 11-37.

Durbin, E., Kane, J., 2007. Seasonal and spatial dynamics of Centropages typicus and C. hamatus in the western North Atlantic. Prog. Oceanogr. 72, 249-258.

Durbin, E.G., Campbell, R.G., Casas, M.C., Ohman, M.D., Niehoff, B., Runge, J., Wagner, M., 2003. Interannual variation in phytoplankton blooms and zooplankton productivity and abundance in the Gulf of Maine during winter. Mar. Ecol. Prog. Ser. 254, 81-100.

Friedland, K.D., Hare, J.A., Wood, G.B., Col, L.A., Buckley, L.J., Mountain, D.G., Kane, J., Brodziak, J., Lough, R.G., Pilskaln, C.H., 2008. Does the fall phytoplankton bloom control recruitment of Georges Bank haddock, Melanogrammus aeglefinus, through parental condition? Can. J. Fish. Aquat. Sci. 65, 1076-1086.

Friedland, K.D., Hare, J.A., Wood, G.B., Col, L.A., Buckley, L.J., Mountain, D.G., Kane, J., Brodziak, J., Lough, R.G., Pilskaln, C.H., 2009. Does the fall phytoplankton bloom control recruitment of Georges Bank haddock, Melanogrammus aeglefinus, through parental condition? Can. J. Fish. Aquat. Sci. 65, 1076-1086.
Friedland, K.D., Kane, J., Hare, J.A., Lough, R.G., Fratantoni, P.S., Fogarty, M.J., Nye, J.A., 2013. Thermal habitat constraints on zooplankton species associated with Atlantic cod (Gadus morhua) on the US Northeast Continental Shelf. Prog Oceanogr 116, 1-13.

Friedland, K.D., Stock, C., Drinkwater, K.F., Link, J.S., Leaf, R.T., Shank, B.V., Rose, J.M. Pilskaln, C.H., Fogarty, M.J., 2012. Pathways between primary production and fisheries yields of large marine ecosystems. PLoS One, 7.

Friedland, K.D., Todd, C.D., 2012. Changes in Northwest Atlantic Arctic and Subarctic conditions and the growth response of Atlantic salmon. Pol. Biol. 35, 593-609.

Gallienne, C.P., Robins, D.B., 2001. Is Oithona the most important copepod in the world's oceans? J. Plankton Res. 23, 1421-1432.

Gamble, J.C., 1978. Copepod grazing during a declining spring phytoplankton bloom in Northern North-Sea. Mar. Biol. 49, 303-315.

Greene, C.H., Monger, B.C., McGarry, L.P., Connelly, M.D., Schnepf, N.R., Pershing, A. J., Belkin, I.M., Fratantoni, P.S., Mountain, D.G., Pickart, R.S., Ji, R.B., Bisagni, J.J., Chen, C.S., Hakkinen, S.M.A., Haidvogel, D.B., Wang, J., Head, E., Smith, P., Conversi, A., M.E.R.C, N., 2012. Recent Arctic climate change and its remote forcing of Northwest Atlantic Shelf ecosystems. Oceanography 25, 208-213.

Hansen, P.J., Bjornsen, P.K., Hansen, B.W., 1997. Zooplankton grazing and growth: scaling within the $2-2,000 \mu \mathrm{m}$ body size range. Limnol. Oceanogr. 42, 687-704.

Hare, J.A., Kane, J., 2012. Zooplankton of the Gulf of Maine - a changing perspective In: Stephenson, R., Annala, J., Hall-Arber, M., Runge, J. (Eds.), Advancing Ecosystem Research for the Future of the Gulf of Maine. American Fisheries Society, Bethesda, Maryland, pp. 1-23.

Harris, R.P., Wiebe, P.H., Lenz, J., Skjldal, H.R., Huntley, M., 2000. ICES Zooplankton Methodology Manual. Academic Press, London, UK.

Heath, M.R., Lough, R.G., 2007. A synthesis of large-scale patterns in the planktonic prey of larval and juvenile cod (Gadus morhua). Fish. Oceanogr. 16, 169-185.

Henson, S.A., Dunne, J.P., Sarmiento, J.L., 2009. Decadal variability in North Atlantic phytoplankton blooms. J. Geophys. Res.: Oceans, 114.

Henson, S.A., Thomas, A.C., 2007. Interannual variability in timing of bloom initiation in the California Current System. J. Geophys. Res.: Oceans, 112.

Hjort, J., 1914. Fluctuations in the great fisheries of northern Europe, viewed in the light of biological research. Rapports et Proce's-Verbaux des Re'unions du Conseil Permanent International pour l'Exploration de la Mer 20, 1-228.

Hlaili, A.S., Niquil, N., Legendre, L., 2014. Planktonic food webs revisited: reanalysis of results from the linear inverse approach. Prog. Oceanogr. 120, 216-229.

Hordoir, R., Meier, H.E.M., 2012. Effect of climate change on the thermal stratification of the baltic sea: a sensitivity experiment. Clim. Dyn. 38, 1703-1713.

Hunt, G.L., Coyle, K.O., Eisner, L.B., Farley, E.V., Heintz, R.A., Mueter, F., Napp, J.M. Overland, J.E., Ressler, P.H., Salo, S., Stabeno, P.J., 2011. Climate impacts on eastern Bering Sea foodwebs: a synthesis of new data and an assessment of the oscillating control hypothesis. ICES J. Mar. Sci. 68, 1230-1243.

Hunt, G.L., Stabeno, P., Walters, G., Sinclair, E., Brodeur, R.D., Napp, J.M., Bond, N.A. 2002. Climate change and control of the southeastern Bering Sea pelagic ecosystem. Deep-Sea Res. II: Top. Stud. Oceanogr. 49, 5821-5853.

Hunt, G.L., Stabeno, P.J., 2002. Climate change and the control of energy flow in the southeastern Bering Sea. Prog. Oceanogr. 55, 5-22.

Irigoien, X., Harris, R.P., Head, R.N., Harbour, D., 2000. North Atlantic Oscillation and spring bloom phytoplankton composition in the English Channel. J Plankton Res. 22, 2367-2371.

Isari, S., Anto, M., Saiz, E., 2013. Copepod foraging on the basis of food nutritional quality: can copepods really choose? PLoS One, 8.

Ji, R.B., Davis, C.S., Chen, C.S., Townsend, D.W., Mountain, D.G., Beardsley, R.C., 2007. Influence of ocean freshening on shelf phytoplankton dynamics. Geophys. Res. Lett. 34, L24607.

Ji, R.B., Davis, C.S., Chen, C.S., Townsend, D.W., Mountain, D.G., Beardsley, R.C., 2008 Modeling the influence of low-salinity water inflow on winter-spring phytoplankton dynamics in the Nova Scotian Shelf-Gulf of Maine region. J. Plankton Res. 30, 1399-1416.

Johnson, C., Pringle, J., Chen, C.S., 2006. Transport and retention of dormant copepods in the Gulf of Maine. Deep-Sea Res. II: Top. Stud. Oceanogr. 53, 2520-2536.

Johnson, C.L., Leising, A.W., Runge, J.A., Head, E.J.H., Pepin, P., Plourde, S., Durbin, E. G., 2008. Characteristics of Calanus finmarchicus dormancy patterns in the Northwest Atlantic. ICES: J. Mar. Sci. 65, 339-350.

Kane, J., 2007. Zooplankton abundance trends on Georges Bank, 1977-2004. ICES: J. Mar. Sci. 64, 909-919.

Kiorboe, T., Nielsen, T.G., 1994. Regulation of zooplankton biomass and production in a temperate, coastal ecosystem.1. Copepods. Limnol. Oceanogr. 39, 493-507.

Kirby, R.R., Beaugrand, G., Lindley, J.A., 2008. Climate-induced effects on the meroplankton and the benthic-pelagic ecology of the North Sea. Limnol. Oceanogr. 53, 1805-1815.

Kristiansen, T., Drinkwater, K.F., Lough, R.G., Sundby, S., 2011. Recruitment variability in North Atlantic Cod and match-mismatch dynamics. PLoS One, 1-10.

Leaf, R.T., Friedland, K.D., 2014. Autumn bloom phenology and magnitude influence haddock recruitment on Georges Bank. ICES: J. Mar. Sci. 71, 2017-2025.

Legendre, L., 1990. The significance of microalgal blooms for fisheries and for the export of particulate organic-carbon in oceans. J. Plankton Res. 12, 681-699.

Leiknes, O., Striberny, A., Tokle, N.E., Olsen, Y., Vadstein, O., Sommer, U., 2014. Feeding selectivity of Calanus finmarchicus in the Trondheimsfjord. J. Sea Res. 85, 292-299.

Longhurst, A., 1995. Seasonal cycles of pelagic production and consumption. Prog. Oceanogr. 36, 77-167.

Lucey, S.M., Fogarty, M.J., 2013. Operational fisheries in New England: linking current fishing patterns to proposed ecological production units. Fish. Res. 141, $3-12$. 
Mackas, D.L., Greve, W., Edwards, M., Chiba, S., Tadokoro, K., Eloire, D., Mazzocchi, M.G., Batten, S., Richardson, A.J., Johnson, C., Head, E., Conversi, A., Peluso, T., 2012. Changing zooplankton seasonality in a changing ocean: comparing time series of zooplankton phenology. Prog. Oceanogr. 97, 31-62.

Mahadevan, A., D’Asaro, E., Lee, C., Perry, M.J., 2012. Eddy-driven stratification initiates North Atlantic spring phytoplankton blooms. Science 337, 54-58.

Marrari, M., Signorini, S.R., Mcclain, C.R., Pajaro, M., Martos, P., Vinas, M.D., Hansen, J., Dimauro, R., Cepeda, G., Buratti, C., 2013. Reproductive success of the Argentine anchovy, Engraulis anchoita, in relation to environmental variability at a mid-shelf front (Southwestern Atlantic Ocean). Fish. Oceanogr. 22, 247-261.

McGillicuddy, D.J., Anderson, L.A., Bates, N.R., Bibby, T., Buesseler, K.O., Carlson, C.A., Davis, C.S., Ewart, C., Falkowski, P.G., Goldthwait, S.A., Hansell, D.A., Jenkins, W. J., Johnson, R., Kosnyrev, V.K., Ledwell, J.R., Li, Q.P., Siegel, D.A., Steinberg, D.K., 2007. Eddy/wind interactions stimulate extraordinary mid-ocean plankton blooms. Science 316, 1021-1026.

Mills, K.E., Pershing, A.J., Brown, C.J., Chen, Y., Chiang, F.S., Holland, D.S., Lehuta, S Nye, J.A., Sun, J.C., Thomas, A.C., Wahle, R.A., 2013. Fisheries management in a changing climate lessons from the 2012 ocean heat wave in the Northwest Atlantic. Oceanography 26, 191-195.

Mousing, E.A., Ellegaard, M., Richardson, K., 2014. Global patterns in phytoplankton community size structure-evidence for a direct temperature effect. Mar. Ecol. Prog. Ser. 497, 25.

Navarro, G., Caballero, I., Prieto, L., Vazquez, A., Flecha, S., Huertas, I.E., Ruiz, J., 2012 Seasonal-to-interannual variability of chlorophyll-a bloom timing associated with physical forcing in the Gulf of Cadiz. Adv. Space Res. 50, 1164-1172.

O'Reilly, J.E., Zetlin, C., 1998. Seasonal, horizontal, and vertical distribution of phytoplankton chlorophyll a in the Northeast U.S. Continental Shelf Ecosystem. NOAA Technical Report NMFS 139. NOAA/National Marine Fisheries Service, Seattle, Washington.

Parsons, T.R., 1988. Trophodynamic phasing in theoretical, experimental and natural pelagic ecosystems. J. Oceanogr. Soc. Jpn. 44, 94-101.

Pershing, A.J., Greene, C.H., Jossi, J.W., O’Brien, L., Brodziak, J.K.T., Bailey, B.A., 2005 Interdecadal variability in the Gulf of Maine zooplankton community, with potential impacts on fish recruitment. ICES J. Mar. Sci. 62, 1511-1523.

Pershing, A.J., Head, E.H.J., Greene, C.H., Jossi, J.W., 2010. Pattern and scale of variability among Northwest Atlantic Shelf plankton communities. J. Plankton Res. 32, 1661-1674.

Pershing, A.J., Record, N.R., Monger, B.C., Mayo, C.A., Brown, M.W., Cole, T.V.N., Kenney, R.D., Pendleton, D.E., Woodard, L.A., 2009. Model-based estimates of right whale habitat use in the Gulf of Maine. Mar. Ecol. Prog. Ser 378, 245-257.

Pierson, J.J., Batchelder, H., Saumweber, W., Leising, A., Runge, J., 2013. The impact of increasing temperatures on dormancy duration in Calanus finmarchicus. J. Plankton Res. 35, 504-512.

Platt, T., Fuentes-Yaco, C., Frank, K.T., 2003. Spring algal bloom and larval fish survival. Nature 423, 398-399.

Polimene, L., Brunet, C., Butenschon, M., Martinez-Vicente, V., Widdicombe, C., Torres, R., Allen, J.I., 2014. Modelling a light-driven phytoplankton succession. J. Plankton Res. 36, 214-229.

Racault, M.F., Le Quere, C., Buitenhuis, E., Sathyendranath, S., Platt, T., 2012. Phytoplankton phenology in the global ocean. Ecol. Indic. 14, 152-163.

Reynolds, R.W., Smith, T.M., Liu, C., Chelton, D.B., Casey, K.S., Schlax, M.G., 2007. Daily high-resolution-blended analyses for sea surface temperature. J. Clim. 20 5473-5496.

Rodionov, Sergei N., 2006. Use of prewhitening in climate regime shift detection. Geophys. Res. Lett. 33, 1-4. http://dx.doi.org/10.1029/2006gl025904.

Rodionov, S.N., 2004. A sequential algorithm for testing climate regime shifts. Geophys. Res. Lett. 31, 1-4. http://dx.doi.org/10.1029/2004gl019448.

Sasaoka, K., Chiba, S., Saino, T., 2011. Climatic forcing and phytoplankton phenology over the subarctic North Pacific from 1998 to 2006, as observed from ocean color data. Geophys. Res. Lett. 38, 1-6.

Saumweber, W.J., Durbin, E.G., 2006. Estimating potential diapause duration in Calanus finmarchicus. Deep-Sea Res. II: Top. Stud. Oceanogr. 53, 2597-2617.

Schweigert, J.F., Thompson, M., Fort, C., Hay, D.E., Therriault, T.W., Brown, L.N., 2013 Factors linking Pacific herring (Clupea pallasi) productivity and the spring plankton bloom in the Strait of Georgia, British Columbia, Canada. Prog. Oceanogr. 115, 103-110.

Sherman, K., Jaworski, N.A., Smayda, T.J., 1996. The Northeast Shelf Ecosystem: Assessment, Sustainability, and Management, Cambridge, MA. Blackwell Science.

Shiozaki, T., Ito, S.I., Takahashi, K., Saito, H., Nagata, T., Furuya, K., 2014. Regional variability of factors controlling the onset timing and magnitude of spring algal blooms in the northwestern North Pacific. J. Geophys. Res.: Oceans 119 253-265.

Siegel, D.A., Doney, S.C., Yoder, J.A., 2002. The North Atlantic spring phytoplankton bloom and Sverdrup's critical depth hypothesis. Science 296, 730-733.

Sommer, U., Lengfellner, K., 2008. Climate change and the timing, magnitude, and composition of the phytoplankton spring bloom. Glob. Change Biol. 14, 1199-1208.

Song, H.J., Ji, R.B., Stock, C., Kearney, K., Wang, Z.L., 2011. Interannual variability in phytoplankton blooms and plankton productivity over the Nova Scotian Shelf and in the Gulf of Maine. Mar. Ecol. Prog. Ser. 426, 105-U133.

Song, H.J., Ji, R.B., Stock, C., Wang, Z.L., 2010. Phenology of phytoplankton blooms in the Nova Scotian Shelf-Gulf of Maine region: remote sensing and modeling analysis. J. Plankton Res. 32, 1485-1499.

Soreide, J.E., Leu, E., Berge, J., Graeve, M., Falk-Petersen, S., 2010. Timing of blooms, algal food quality and Calanus glacialis reproduction and growth in a changing Arctic. Glob. Change Biol. 16, 3154-3163.

Sosik, H.M., Green, R.E., Pegau, W.S., Roesler, C.S., 2001. Temporal and vertical variability in optical properties of New England shelf waters during late summer and spring. J. Geophys. Res.: Oceans 106, 9455-9472.

Steinberg, D.K., Lomas, M.W., Cope, J.S., 2012. Long-term increase in mesozooplankton biomass in the Sargasso Sea: linkage to climate and implications for food web dynamics and biogeochemical cycling. Glob. Biogeochem. Cycles 26, $1-16$.

Sydeman, W.J., Santora, J.A., Thompson, S.A., Marinovic, B., Di Lorenzo, E., 2013. Increasing variance in North Pacific climate relates to unprecedented ecosystem variability off California. Glob. Change Biol. 19, 1662-1675.

Taboada, F.G., Anadon, R., 2014. Seasonality of North Atlantic phytoplankton from space: impact of environmental forcing on a changing phenology (1998-2012). Glob. Change Biol. 20, 698-712.

Thomalla, S.J., Fauchereau, N., Swart, S., Monteiro, P.M.S., 2011. Regional scale characteristics of the seasonal cycle of chlorophyll in the Southern Ocean. Biogeosciences 8, 2849-2866.

Thomas, A.C., Townsend, D.W., Weatherbee, R., 2003. Satellite-measured phytoplankton variability in the Gulf of Maine. Cont. Shelf Res. 23, 971-989.

Tommasi, D., Hunt, B.P.V., Pakhomov, E.A., Mackas, D.L., 2013a. Mesozooplankton community seasonal succession and its drivers: Insights from a British Columbia, Canada, fjord. J. Mar. Syst. 115, 10-32.

Tommasi, D.A.G., Routledge, R.D., Hunt, B.P.V., Pakhomov, E.A., 2013b. The seasonal development of the zooplankton community in a British Columbia (Canada) fjord during two years with different spring bloom timing. Mar. Biol. Res. 9, 129-144.

Townsend, D.W., Keller, M.D., Sieracki, M.E., Ackleson, S.G., 1992. Spring phytoplankton blooms in the absence of vertical water column stratification. Nature 360, 59-62.

Townsend, D.W., Rebuck, N.D., Thomas, M.A., Karp-Boss, L., Gettings, R.M., 2010. A changing nutrient regime in the Gulf of Maine. Cont. Shelf Res. 30, 820-832.

Townsend, D.W., Thomas, A.C., Mayer, L.M., Thomas, M., Quinlan, J., 2006. Oceanography of the Northwest Atlantic continental shelf In: Robinson, A.R., Brink, K.H. (Eds.), The Sea. Harvard University Press, Cambridge, pp. 119-168.

Trzcinski, M.K., Devred, E., Platt, T., Sathyendranath, S., 2013. Variation in ocean colour may help predict cod and haddock recruitment. Mar. Ecol. Prog. Ser. 491, 187-197.

Wassmann, P., 1998. Retention versus export food chains: processes controlling sinking loss from marine pelagic systems. Hydrobiologia 363, 29-57.

Winder, M., Sommer, U., 2012. Phytoplankton response to a changing climate. Hydrobiologia 698, 5-16.

Woodland, R.J., Secor, D.H., 2013. Benthic-pelagic coupling in a temperate inner continental shelf fish assemblage. Limnol. Oceanogr. 58, 966-976.

Xu, Y., Chant, R., Gong, D.L., Castelao, R., Glenn, S., Schofield, O., 2011. Seasonal variability of chlorophyll a in the Mid-Atlantic Bight. Cont. Shelf Res. 31, 1640-1650.

Yamada, K., Ishizaka, J., 2006. Estimation of interdecadal change of spring bloom timing, in the case of the Japan Sea. Geophys. Res. Lett. 33, 1-4.

Zhai, L., Platt, T., Tang, C., Sathyendranath, S., Walne, A., 2013. The response of phytoplankton to climate variability associated with the North Atlantic Oscillation. Deep-Sea Res. II: Top. Stud. Oceanogr. 93, 159-168.

Zhao, H., Han, G.Q., Wang, D.X., 2013. Timing and magnitude of spring bloom and effects of physical environments over the Grand Banks of Newfoundland. J. Geophys. Res.: Biogeosci. 118, 1385-1396. 